\title{
Mutation of Lon Protease Differentially Affects the Expression of Pseudomonas syringae Type III Secretion System Genes in Rich and Minimal Media and Reduces Pathogenicity
}

\author{
Lefu Lan, ${ }^{1}$ Xin Deng, ${ }^{1}$ Yanmei Xiao, ${ }^{1}$ Jian-Min Zhou, ${ }^{2}$ and Xiaoyan Tang ${ }^{1}$ \\ ${ }^{1}$ Department of Plant Pathology, Kansas State University, Manhattan, 66506-5502, U.S.A.; ${ }^{2}$ National Institute of Biological \\ Sciences, Beijing, China
}

Submitted 17 October 2006. Accepted 12 February 2007.

\begin{abstract}
The bacterial Lon protease participates in a variety of biological processes. In Pseudomonas syringae, mutation of lon is known to activate $h r p L$ and a few $h r p L$-regulated genes in rich medium. The elevated expression of $h r p L$ and $h r p L-$ regulated genes results from increased stability of HrpR, the transcriptional activator of $h r p L$, in the lon mutant. Here, we conducted a microarray analysis to identify genes that are differentially expressed in a $\operatorname{lon}^{-}$mutant of $P$. syringae pv. tomato DC3000 grown in the rich medium King's $\mathrm{B}$ (KB). Most genes induced in the $l^{-}{ }^{-}$mutant belong to the $H r p L$ regulon or are related to transcription, protein synthesis, and energy metabolism. A major group of genes reduced in the $l o n^{-}$mutant are related to cell wall biogenesis. The HrpL-regulated genes exhibit different induction patterns in the $l o n^{-}$mutant, suggesting that additional regulators other than $\mathrm{HrpL}$ are likely to be involved in regulation of these genes. Compared with the wild-type bacteria, lon $^{-}$mutants of $P$. syringae pv. tomato DC3000 and $P$. syringae pv. phaseolicola NPS3121 strains exhibit elevated $h r p L$ expression in KB medium, but reduced $h r p L$ expression in minimal medium (MM). The reduced $h r p L$ RNA is correlated with reduced $h r p R$ and $h r p S$ RNAs, suggesting that the Lon-mediated regulation of $h r p L$ involves different mechanisms in KB and MM. The $\operatorname{lon}^{-}$mutation also reduced bacterial pathogenicity.
\end{abstract}

The bacterial Lon protein is an ATP-dependent protease participating in the degradation of a variety of abnormal or denatured proteins and is believed to play an important role in amino acid recycling under stringent conditions (Kuroda 2006; Kuroda et al. 2001). Lon also is able to recognize and specifically degrade a number of regulatory proteins (Tsilibaris et al. 2006). Mutation of lon was reported to affect a number of biological processes in various bacteria, including cell division (Schoemaker et al. 1984), capsule synthesis (Torres-Cabassa and Gottesman 1987), flagella biosynthesis (Stewart et al. 1997), UV tolerance (Howard-Flanders et al. 1964; Whistler et al. 2000), and antibiotic production (Whistler et al. 2000). The biological pathways affected by the $l o n^{-}$mutation vary in dif-

Corresponding author: Xiaoyan Tang; Telephone: +1.785 .532 .1345 ; Fax: +1.785.532.5692; E-mail: xtang@ksu.edu

* The $\boldsymbol{e}$-Xtra $\log$ o stands for "electronic extra" and indicates that a supplemental figure not included in the print edition is available online. ferent bacterial species. For example, the $\operatorname{lon}^{-}$mutant of $E s$ cherichia coli exhibits increased sensitivity to UV irradiation (Howard-Flanders et al. 1964), a defect in cell division resulting in filamentation (Howard-Flanders et al. 1964), and increased exopolysaccharide synthesis leading to mucoidy (Markovitz 1964). However, mutation of lon in Agrobacterium tumefaciens does not affect sensitivity to UV irradiation or exopolysaccharide synthesis, and the mutant cells do not form filaments ( $\mathrm{Su}$ et al. 2006). Lon also was reported to regulate the type III secretion system (TTSS) negatively in Salmonella spp. and positively in Yersinia spp. In Salmonella spp., Lon was found to degrade HilC and HilD, two positive transcriptional regulators of the TTSS genes in pathogenicity island 1 (Takaya et al. 2005). In Yersinia spp., Lon was reported to degrade YmoA, a histone-like protein that represses the expression of plasmid-encoded TTSS genes and, thus, allows elevated expression of the TTSS genes (Jackson et al. 2004).

Lon was first detected in Pseudomonas syringae as a negative regulator of $h r p A$ and $h r p L$ genes in the rich medium King's B (KB) (Bretz et al. 2002). hrpA encodes pilin, a structural protein of the P. syringae type III pilus (Roine et al. 1997). hrpL encodes an alternate sigma factor essential for the induction of $P$. syringae genes carrying hrp box promoters, including hrpA (Xiao et al. 1994). More than 110 genes were shown to be regulated by $\mathrm{HrpL}$ and hrp box promoters in $P$. syringae pv. tomato DC3000 using various experimental methods (Chang et al. 2005; Ferreira et al. 2006; Fouts et al. 2002; Lan et al. 2006; Zwiesler-Vollick et al. 2002). Most of the HrpL-regulated genes encode structural proteins of the TTSS and type III effector proteins, but some apparently have a function independent of TTSS (Chang et al. 2005; Ferreira et al. 2006; Lan et al. 2006; Lindeberg et al. 2006; Petnicki-Ocwieja et al. 2002; Schechter et al. 2006). The HrpL-regulated genes, together with $h r p L$, are repressed in rich media such as KB but induced when the bacteria are cultured in minimal medium (MM) or infiltrated into the plant (Tang et al. 2006; Xiao and Hutcheson 1994). The hrpL induction is mediated by HrpR and HrpS together with the alternate sigma factor RpoN (Hendrickson et al. 2000; Hutcheson et al. 2001; Xiao et al. 1994). RpoN recognizes the $\sigma^{54}$-dependent DNA element in the $h r p L$ promoter and interacts with the RNA polymerase holoenzyme (Hendrickson et al. 2000). HrpR and HrpS are similar in amino acid sequences, and both have the RpoN-interaction domains (Hutcheson et al. 2001). The two proteins form a heterodimer on the $h r p L$ promoter and, together with RpoN, activate $h r p L$ transcription (Hutcheson et al. 2001). The $h r p R$ 
and $h r p S$ genes are organized in an operon controlled by the $h r p R$ promoter, but $h r p S$ also can be transcribed independently under the control of a weak promoter immediately upstream of hrpS (Grimm et al. 1995; Hutcheson et al. 2001). The hrpRS operon is expressed at a relatively high level in rich medium and further induced up to two- to fourfold in MM or in the plant (Rahme et al. 1992; Thwaites et al. 2004; Xiao et al. 2007). In a search for genes required for repression of $h r p A$ in rich medium, $l^{-} n^{-}$mutants were isolated that allowed elevated expression of $h r p A$ and $h r p L$ (Bretz et al. 2002). Further studies indicated that mutation of lon stabilizes HrpR in rich medium, resulting in the constitutive activation of $h r p L$ and downstream TTSS genes (Bretz et al. 2002). In addition to HrpR, Lon also was found to degrade various type III effector proteins (Losada and Hutcheson 2005).

Lon is known to regulate multiple regulatory proteins in other bacterial species, and many of these regulatory proteins have their counterparts in P. syringae (Buell et al. 2003); therefore, the $l^{-}{ }^{-}$mutation in $P$. syringae may affect other biological processes in addition to the TTSS. Indeed, the $P$. syringae lon ${ }^{-}$mutant displays hypersensitivity to UV irradiation, abnormal cell morphology, and filamentation (Bretz et al. 2002). To gain a global view of Lon protease function in $P$. syringae, we conducted a microarray analysis to compare gene expression profiles in the $P$. syringae pv. tomato DC3000 wild-type (WT) and lon $^{-}$mutant strains grown in the rich $\mathrm{KB}$ medium. The assay identified 155 genes induced and 45 genes (excluding lon) reduced in the lon $^{-}$mutant. Some of these differentially expressed genes probably are regulated directly by substrate proteins of the Lon protease, whereas others probably are due to an indirect effect of the lon $^{-}$mutation. We also investigated how mutation of lon affected the expression of TTSS regulatory genes in MM. We found that the lon $^{-}$mutation reduced expression of the TTSS regulatory genes in MM. The $\operatorname{lon}^{-} \mathrm{mu}-$ tants displayed reduced pathogenicity.

\section{RESULTS AND DISCUSSION}

Microarray data analysis and validation by RNA blotting.

Microarray design and analysis were as described by Lan and associates (2006). Of the 5,763 open reading frames (ORF) predicted in the DC3000 genome, 5,608 were represented by the array. To identify genes differentially expressed in the lon $^{-}$mutant, total RNA samples were prepared from WT DC3000 and the lon $^{-}$mutant growing in $\mathrm{KB}$ liquid medium at log phase. The RNA sample was fluorescently labeled and hybridized to the array. Three biological replicates were performed for each sample. The replicate samples showed a high correlation in $\log _{2}$ relative fluorescence intensities (Table 1), demonstrating good reproducibility of the microarray data.

The RNA levels of the 5,608 predicted ORF were compared between the lon $^{-}$mutant and the WT strain. The following cutoff criteria were combined for the identification of differentially expressed genes: $1,>2$-fold difference; $2,>1.32$-fold difference but with significance values of $P<0.1$ ( $t$ test); and 3 , $>1.32$-fold difference with $P>0.1$ but clustering with genes of the first two groups. In all, 155 genes (Table 2) were considered to be induced and 46 genes (Table 3 ) reduced in the lon mutant.

To validate the microarray data, seven genes representing a wide range of relative fluorescence signal intensities and different gene expression profiles were subjected to RNA blot analysis. All the genes displayed the expected differential expression pattern (Fig. 1). In addition, hrpL and three HrpLregulated genes that were indicated by microarray as differentially expressed also displayed the expected patterns in Northern analysis (Fig. 2A and B). These results indicated that the differential expression data obtained by microarray analysis are largely reliable.

\section{Genes upregulated in the lon $^{-}$mutant.}

Of the 155 genes upregulated in the lon mutant, 39 genes belonged to the HrpL-regulon (Ferreira et al. 2006; Lan et al. 2006). Consistent with a previous report (Bretz et al. 2002), $h r p L$ also was induced in the $l o n^{-}$mutant (Table 2; Fig. 2). The induction of $h r p L$ likely plays a central role in the induction of these genes in the lon $^{-}$mutant.

Seven genes had putative functions in transcription and global transcriptional regulation. These included an RNA polymerase alpha subunit (PSPTO0651), an RNA polymerase sigma factor sigW (PSPTO2298), a transcription elongation factor (PSPTO4491), a transcription antitermination protein

Table 1. Pearson correlations of the replicate (Rep) microarray hybridizations $^{\mathrm{a}}$

\begin{tabular}{lccc}
\hline Samples $^{\text {b }}$ & Rep 1 vs. Rep 2 & Rep 1 vs. Rep 3 & Rep 2 vs. Rep 3 \\
\hline WT-KB & 0.91 & 0.84 & 0.88 \\
lon $^{-}-\mathrm{KB}$ & 0.95 & 0.94 & 0.94 \\
\hline
\end{tabular}

a The numbers indicate the correlation of the $\log _{2}$ relative fluorescence intensities of all open reading frames between the replicate samples.

b $\mathrm{WT}-\mathrm{KB}=\mathrm{WT}$ strain in $\mathrm{KB}$, lon $^{-}-\mathrm{KB}=$ lon $^{-}$mutant treated with $\mathrm{KB}$.

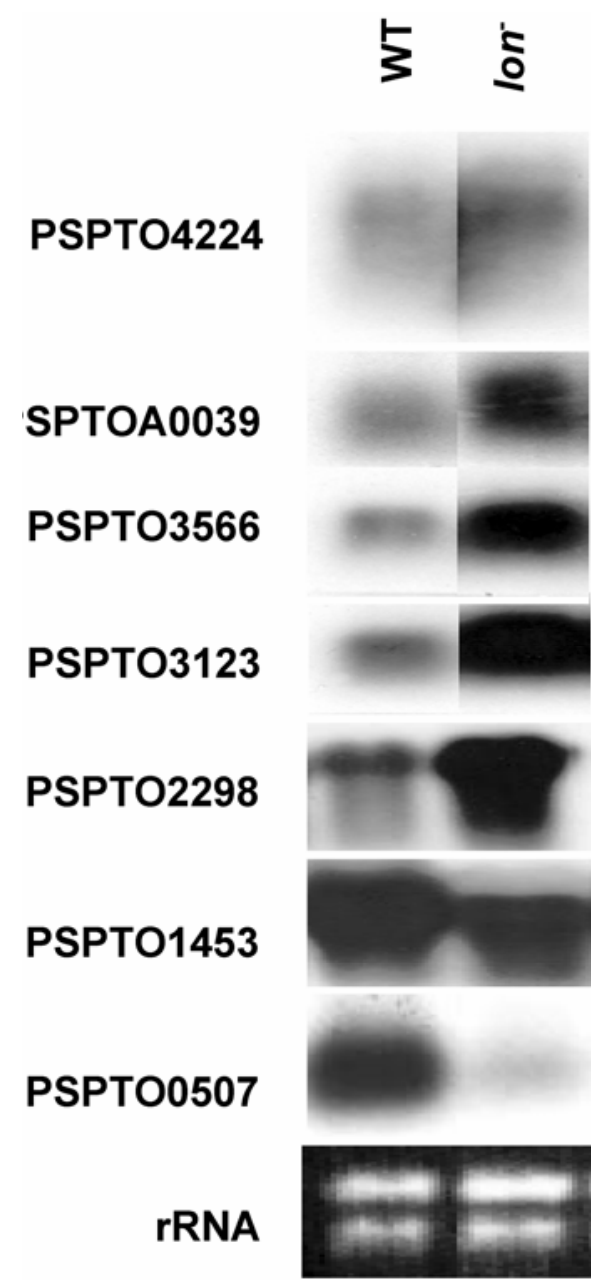

Fig. 1. Verification of the microarray data by Northern blotting. The coding region of each gene was polymerase chain reaction (PCR) amplified and radiolabeled with ${ }^{32} \mathrm{P}-\mathrm{dCTP}$ as probes. All genes were tested with the same RNA samples. Equal loading of RNA samples is indicated by rRNA fragments in ethidium bromide-stained gels. The composite bands for each probe were from the same Northern hybridization and autoradiography. 
Table 2. Genes induced in the DC3000 lon $^{-}$mutant

\begin{tabular}{|c|c|c|}
\hline PSPTO no. and description & lon $^{-}-K B$ vs. WT-KB (fold) ${ }^{a}$ & $P$ value \\
\hline \multicolumn{3}{|l|}{ HrpL regulon and HrpL (40) } \\
\hline PSPTO1404 HrpL & 1.380 & 0.216 \\
\hline PSPTO0044 HopK1 & 1.581 & 0.053 \\
\hline PSPTO0061 HopY1 & 1.459 & 0.075 \\
\hline PSPTO0371 indoleacetate-lysine ligase & 1.483 & 0.269 \\
\hline PSPTO0503 SchF & 2.461 & 0.145 \\
\hline PSPTO0588 HopH1 & 5.123 & 0.105 \\
\hline PSPTO0589 HopC1 & 6.566 & 0.094 \\
\hline PSPTO0834 alcohol dehydrogenase zinc-containing & 4.141 & 0.115 \\
\hline PSPTO0835 ribD C-terminal domain protein & 3.084 & 0.058 \\
\hline PSPTO0836 conserved domain protein & 2.228 & 0.118 \\
\hline PSPTO0837 conserved hypothetical & 2.176 & 0.062 \\
\hline PSPTO0873 amidinotransferase family protein & 7.906 & 0.138 \\
\hline PSPTO0874 nikkomycin biosynthesis domain protein & 2.270 & 0.111 \\
\hline PSPTO0875 Homolog of PSPTO0874 & 1.519 & 0.067 \\
\hline PSPTO1022 HopAM1-1 & 10.070 & 0.107 \\
\hline PSPTO1369 ShcN & 3.154 & 0.073 \\
\hline PSPTO1373 HrpW & 2.333 & 0.130 \\
\hline PSPTO1381 HrpA & 5.271 & 0.117 \\
\hline PSPTO1382 HrpZ & 3.281 & 0.160 \\
\hline PSPTO1383 HrpB & 1.895 & 0.180 \\
\hline PSPTO1384 HrcJ & 1.862 & 0.047 \\
\hline PSPTO1387 HrpF & 2.648 & 0.131 \\
\hline PSPTO1389 HrcC & 1.604 & 0.118 \\
\hline PSPTO1390 HrpT & 1.326 & 0.028 \\
\hline PSPTO1391 HrpV & 1.422 & 0.126 \\
\hline PSPTO1399 HrpO & 1.563 & 0.242 \\
\hline PSPTO1405 HrpK & 1.502 & 0.256 \\
\hline PSPTO1408 hypothetical protein & 2.088 & 0.114 \\
\hline PSPTO1409 conserved hypothetical protein & 1.581 & 0.031 \\
\hline PSPTO3087 AvrPtoB & 1.971 & 0.176 \\
\hline PSPTO4001 AvrPto & 7.819 & 0.081 \\
\hline PSPTO4101 HopAK1 & 1.360 & 0.141 \\
\hline PSPTO4331 HopE1 & 6.864 & 0.082 \\
\hline PSPTO4599 ShcS1 & 1.393 & 0.206 \\
\hline PSPTO4703 hopAQ1 & 2.385 & 0.193 \\
\hline PSPTO4776 HopPmaI & 1.955 & 0.096 \\
\hline PSPTO5353 SchA & 1.524 & 0.051 \\
\hline PSPTOA0005 HopAM1-1 & 9.241 & 0.100 \\
\hline PSPTOA0017 ShcO1 & 3.063 & 0.045 \\
\hline PSPTOA0018 HopO1-1 & 4.053 & 0.205 \\
\hline \multicolumn{3}{|l|}{ Transcription and transcriptional regulation (7) } \\
\hline PSPTO0614 transcription antitermination protein NusG & 3.025 & 0.056 \\
\hline PSPTO0651 DNA-directed RNA polymerase $\alpha$ subunit & 1.676 & 0.113 \\
\hline PSPTO1274 cold shock domain family protein & 1.401 & 0.079 \\
\hline PSPTO2298 RNA polymerase sigma factor-70 sigW, putative & 1.597 & 0.029 \\
\hline PSPTO3723 DNA-binding protein HU- $\beta$ & 1.477 & 0.003 \\
\hline PSPTO4145 cold shock protein CapB & 2.178 & 0.118 \\
\hline PSPTO4491 transcription elongation factor NusA & 1.808 & 0.060 \\
\hline \multicolumn{3}{|l|}{ Protein synthesis $(51)$} \\
\hline PSPTO0089 ribosomal protein L28 & 1.833 & 0.065 \\
\hline PSPTO0090 ribosomal protein L33 & 1.523 & 0.212 \\
\hline PSPTO0539 ribosomal protein S21 & 3.593 & 0.016 \\
\hline PSPTO0616 ribosomal protein L1 & 1.646 & 0.216 \\
\hline PSPTO0617 ribosomal protein L10 & 1.936 & 0.058 \\
\hline PSPTO0618 ribosomal protein L7/L12 & 1.750 & 0.041 \\
\hline PSPTO0621 ribosomal protein S12 & 1.618 & 0.091 \\
\hline PSPTO0622 ribosomal protein S7 & 1.421 & 0.345 \\
\hline PSPTO0625 ribosomal protein S10 & 1.723 & 0.100 \\
\hline PSPTO0626 ribosomal protein L3 & 1.536 & 0.361 \\
\hline PSPTO0627 ribosomal protein L4 & 1.583 & 0.135 \\
\hline PSPTO0629 ribosomal protein L2 & 1.449 & 0.292 \\
\hline PSPTO0640 ribosomal protein S8 & 1.957 & 0.032 \\
\hline PSPTO0641 ribosomal protein L6 & 1.648 & 0.079 \\
\hline PSPTO0642 ribosomal protein L18 & 1.514 & 0.311 \\
\hline PSPTO0643 ribosomal protein S5 & 1.427 & 0.346 \\
\hline PSPTO0644 ribosomal protein L30 & 1.331 & 0.310 \\
\hline PSPTO0647 ribosomal protein L36 & 1.816 & 0.092 \\
\hline PSPTO0648 ribosomal protein S13 & 2.073 & 0.043 \\
\hline \multirow[t]{2}{*}{ PSPTO0649 ribosomal protein S11 } & 1.657 & 0.151 \\
\hline & & (continued \\
\hline
\end{tabular}

\footnotetext{
${ }^{a}$ The lon $^{-}$mutant treated with the rich medium King' B (lon ${ }^{-}-\mathrm{KB}$ ) versus the wild type treated with $\mathrm{KB}$ (WT-KB); numbers indicate the fold of induction in lon $^{-}-\mathrm{KB}$.
} 
Table 2. (continued from preceding page)

\begin{tabular}{|c|c|c|}
\hline PSPTO no. and description & lon $^{-}$-KB vs. WT-KB (fold) ${ }^{a}$ & $P$ value \\
\hline Protein synthesis (51) (continued) & Protein synthesis (51) & Protein synthesis (51) \\
\hline PSPTO0650 ribosomal protein S4 & 1.631 & 0.148 \\
\hline PSPTO0652 ribosomal protein L17 & 1.640 & 0.213 \\
\hline PSPTO0797 ribosomal protein L21 & 2.509 & 0.027 \\
\hline PSPTO0798 ribosomal protein L27 & 1.587 & 0.065 \\
\hline PSPTO0802 ribosomal protein S20 & 2.914 & 0.002 \\
\hline PSPTO1103 50S ribosomal protein L25 & 1.879 & 0.049 \\
\hline PSPTO1473 ribosomal protein S16 & 2.583 & 0.031 \\
\hline PSPTO1474 16S rRNA processing protein RimM & 2.772 & 0.014 \\
\hline PSPTO1475 tRNA (guanine-N1)-methyltransferase & 3.901 & 0.120 \\
\hline PSPTO1476 ribosomal protein L19 & 1.803 & 0.101 \\
\hline PSPTO1533 methionine aminopeptidase type I & 1.375 & 0.059 \\
\hline PSPTO1534 ribosomal protein S2 & 1.674 & 0.185 \\
\hline PSPTO1535 translation elongation factor Ts & 1.747 & 0.063 \\
\hline PSPTO1765 translation elongation factor P & 1.763 & 0.040 \\
\hline PSPTO2378 threonyl-tRNA synthetase & 1.399 & 0.093 \\
\hline PSPTO2379 translation initiation factor IF-3 & 1.843 & 0.075 \\
\hline PSPTO2380 ribosomal protein L35 & 1.863 & 0.111 \\
\hline PSPTO2381 ribosomal protein L20 & 2.061 & 0.078 \\
\hline PSPTO3352 translation initiation factor IF-1 & 3.114 & 0.013 \\
\hline PSPTO3727 ribosome-binding & 1.618 & 0.091 \\
\hline PSPTO3835 ribosomal protein L32 & 3.387 & 0.071 \\
\hline PSPTO4426 ribosomal protein L13 & 2.370 & 0.037 \\
\hline PSPTO4487 ribosomal protein S15 & 1.587 & 0.180 \\
\hline PSPTO4489 ribosome-binding factor A & 1.382 & 0.031 \\
\hline PSPTO4490 translation initiation factor IF-2 & 1.331 & 0.477 \\
\hline PSPTO4930 ribosomal protein L9 & 2.415 & 0.151 \\
\hline PSPTO4932 ribosomal protein S18 & 2.151 & 0.184 \\
\hline PSPTO4933 ribosomal protein S6 & 2.124 & 0.042 \\
\hline PSPTO5136 ribosomal protein L31 & 2.405 & 0.054 \\
\hline PSPTO5614 ribonuclease $\mathrm{P}$ protein component & 2.089 & 0.120 \\
\hline PSPTO5615 ribosomal protein L34 & 2.102 & 0.065 \\
\hline \multicolumn{3}{|l|}{ Protein fate (8) } \\
\hline PSPTO0613 preprotein translocase SecE subunit & 2.721 & 0.008 \\
\hline PSPTO0646 preprotein translocase SecY subunit & 1.795 & 0.115 \\
\hline PSPTO1414 preprotein translocase YajC subunit & 1.462 & 0.003 \\
\hline PSPTO 4376 GroEL chaperonin $60 \mathrm{kDa}$ & 1.524 & 0.008 \\
\hline PSPTO 4377 co-chaperoninGroES protein nin $10 \mathrm{kDa}$ & 1.555 & 0.035 \\
\hline PSPTO4493 preprotein translocase SecG subunit & 2.719 & 0.046 \\
\hline PSPTO4506 heat shock protein GrpE & 1.829 & 0.093 \\
\hline PSPTO5612 inner membrane protein $60 \mathrm{kDa}$ & 1.492 & 0.256 \\
\hline \multicolumn{3}{|l|}{ Energy metabolism (22) } \\
\hline PSPTO1422 rrf2 family protein & 1.378 & 0.115 \\
\hline PSPTO1423 cysteine desulfurase & 1.576 & 0.062 \\
\hline PSPTO1424 iron-binding protein IscU & 1.643 & 0.098 \\
\hline PSPTO1425 iron-binding protein IscA & 1.532 & 0.186 \\
\hline PSPTO1428 ferredoxin 2Fe-2S & 1.383 & 0.333 \\
\hline PSPTO1429 assembly of Fe-S clusters & 1.458 & 0.038 \\
\hline PSPTO1536 uridylate kinase & 1.576 & 0.039 \\
\hline PSPTO1844 carbon storage regulator & 1.563 & 0.099 \\
\hline PSPTO2211 3-hydroxydecanoyl-ACP dehydratase & 1.439 & 0.049 \\
\hline PSPTO2288 2-methylcitrate synthase & 1.500 & 0.069 \\
\hline PSPTO3566 carbon storage regulator & 2.725 & 0.083 \\
\hline PSPTO3831 acyl carrier protein & 1.932 & 0.047 \\
\hline PSPTO3832 3-oxoacyl-(acyl-carrier-protein) reductase & 1.393 & 0.261 \\
\hline PSPTO4161 glutaredoxin-related protein & 1.496 & 0.027 \\
\hline PSPTO 4494 triosephosphate isomerase & 1.971 & 0.034 \\
\hline PSPTO4508 ferric uptake regulation protein & 1.481 & 0.035 \\
\hline PSPTO5600 ATP synthase gamma chain (EC 3.6.3.14) & 1.825 & 0.032 \\
\hline PSPTO5602 ATP synthase delta chain (EC 3.6.3.14) & 1.532 & 0.053 \\
\hline PSPTO5603 ATP synthase B chain (EC 3.6.3.14) & 1.691 & 0.054 \\
\hline PSPTO5604 ATP synthase C chain (EC 3.6.3.14) & 1.535 & 0.138 \\
\hline PSPTO5605 ATP synthase A chain (EC 3.6.3.14) & 1.527 & 0.048 \\
\hline PSPTO5606 ATP synthase protein I & 1.455 & 0.091 \\
\hline \multicolumn{3}{|l|}{ Other functions (11) } \\
\hline PSPTO0433 thiamine biosynthesis protein ThiS & 2.105 & 0.040 \\
\hline PSPTO0513 coenzyme PQQ synthesis protein A & 1.490 & 0.086 \\
\hline PSPTO1104 ribose-phosphate pyrophosphokinase & 1.459 & 0.170 \\
\hline PSPTO1256 amino acid ABC transporter permease protein & 1.360 & 0.033 \\
\hline \multirow[t]{2}{*}{ PSPTO1529 arsC family protein } & 1.983 & 0.054 \\
\hline & & (continued on next page) \\
\hline
\end{tabular}


(PSPTO0614), a global transcriptional regulator (PSPTO3723), and two homologous genes (PSPTO1274 and PSPTO4145) that may function as transcription antiterminators. PSPTO3723 belongs to the DNABII family proteins that bind and bend DNA and function in many cellular processes, including transcriptional regulation (Swinger and Rice 2004). Proteins encoded by PSPTO1274 and PSPTO4145 contain the cold shock DNAbinding domain and are highly homologous to the E. coli CspA protein. CspA is an RNA chaperone that facilitates translation at low temperature by destabilizing mRNA secondary structures. CspA and the homologous RNA chaperones CspE and CspC are transcription antiterminators in E. coli (Bae et al. 2000).

A total of 51 genes may be involved in protein synthesis. Of these, 38 genes encoded ribosomal proteins. The remaining 13 genes may be involved in translation initiation and elongation (PSPTO2379, PSPTO3352, PSPTO4490, PSPTO1535, and PSPTO1765), ribosome-binding (PSPTO1103 and PSPTO3727), tRNA processing and maturation (PSPTO1475, PSPTO2378, and PSPTO5614), 16S RNA processing (PSPTO1474 and PSPTO 4489), and the removal of N-terminal amino acids from peptides (PSPTO1533). It is well known that the Lon protease can degrade ribosomal proteins, and this proteolytic activity plays a critical role in regulating the abundance of ribosomal proteins and, therefore, basic cellular activities (Kuroda 2006). Here, we demonstrated the upregulation of ribosomal protein genes in a lon $^{-}$mutant, suggesting another mechanism through which Lon regulates the abundance of ribosomal proteins.

Additional induced genes appear to be associated with the elevated protein synthesis. Three of these genes encode putative chaperonin proteins that are involved in protein folding and stability (PSPTO4376, PSPTO4377, and PSPTO4506). Another gene (PSPTO5612) has a homologue in E. coli that functions to insert inner membrane proteins into their destination. The induction of this gene was expected because protein synthesis was elevated in the $\operatorname{lon}^{-}$mutant, and a significant portion of these proteins were targeted to cell membranes. Interestingly, four genes with a function in preprotein translocation (PSPTO0613, PSPTO0646, PSPTO1414, and PSPTO4493) also were induced in the lon $^{-}$mutant. The induction of these genes suggests an increase in protein secretion through the general secretion pathway.
Twenty-two genes may be involved in energy metabolism. Six of these genes (PSPTO0560, PSPTO0562, PSPTO0563, PSPTO0564, PSPTO0565, and PSPTO0566) are clustered and encode different subunits of ATP synthase. PSPTO1536 encodes a putative uridylate kinase catalyzing formation of UDP from UMP. Two other genes with putative metabolic functions were PSPTO2288 and PSPTO4494, which encode methyl citrate synthase and triosephosphate isomerase, respectively. PSPTO1844 and PSPTO3566 encode putative carbon storage regulators (CsrA-2 and CsrA-3), which are RNA-binding regulatory proteins that globally regulate carbon metabolism and a variety of other processes (Romeo 1998). Three genes (PSPTO2211, PSPTO3831, and PSPTO3832) are involved in fatty acid and phospholipid metabolism, a process related to energy metabolism as well. A cluster of six genes (PSPTO1422, PSPTO1423, PSPTO1424, PSPTO1425, PSPTO1428, and PSPTO1429) appear to be involved in the synthesis and assembly of Fe-S clusters (Johnson et al. 2005). The Fe-S cluster containing proteins plays an important role in electron transfer processes and in energy production and conversion. PSPTO4508 encodes a ferric-uptake regulatory protein. PSPTO4161 encodes a glutaredoxin-related protein that functions in an Fe-S cluster-dependent manner.

The induction of genes involved in transcription, translation, and energy metabolism suggests elevation of basic cellular activities in the lon $^{-}$mutant. Despite these changes in basic cellular processes, the $l^{-}{ }^{-}$mutants displayed growth similar to the WT strain during log phase in KB liquid culture (data not shown).

In addition to the above three major functional groups, a few genes of various other functions also were induced in the lon mutant. Among them were four genes (PSPTO0433, PSPTO0513, PSPTO1104, and PSPTO4859) encoding putative catalytic enzymes that are involved in biosynthesis of cofactors, amino acids, and nucleotides. Two putative ABC transporters (PSPTO1256 and PSPTO4588) are involved in transport of amino acids and dipeptides. Two genes (PSPTO1529 and PSPTO4442) appear to encode proteins with detoxification functions. TolR encoded by PSPTO3974, together with the TolA, TolB, TolQ, and Pal proteins, may be involved in the maintenance of outer membrane stability (Cascales and Lloubes 2004). MreB, encoded by PSPTO4722, is a putative

Table 2. (continued from preceding page)

\begin{tabular}{lcc}
\hline PSPTO no. and description & lon--KB vs. WT-KB (fold) $^{\mathbf{a}}$ & $\boldsymbol{P}$ value \\
\hline Other functions (11) (continued) & Protein synthesis (51) & Protein synthesis (51) \\
PSPTO3729 lipoprotein, putative & 1.689 & 0.079 \\
PSPTO3974 tolR protein & 1.334 & 0.078 \\
PSPTO4442 toluene tolerance protein, putative & 2.377 & 0.033 \\
PSPTO4472 rod shape-determining protein MreB & 1.552 & 0.104 \\
PSPTO4558 dipeptide ABC transporter, putative & 1.489 & 0.080 \\
PSPTO4859 3-dehydroquinate dehydratase (EC 4.2.1.10) & 1.425 & 0.059 \\
Hypothetical and unknown function (17) & & 0.150 \\
PSPTO0219 hypothetical protein & 1.478 & 0.060 \\
PSPTO0220 conserved hypothetical protein & 1.385 & 0.168 \\
PSPTO0367 conserved hypothetical protein & 2.493 & 0.075 \\
PSPTO0605 HesB/YadR/YfhF family protein & 1.375 & 0.102 \\
PSPTO1840 identified by Glimmer2; putative & 1.784 & 0.048 \\
PSPTO3387 conserved hypothetical protein & 2.387 & 0.079 \\
PSPTO3477 identified by Glimmer2; putative & 1.706 & 0.004 \\
PSPTO3836 hypothetical protein & 4.554 & 0.020 \\
PSPTO3980 hypothetical protein & 1.402 & 0.078 \\
PSPTO4417 hypothetical protein & 1.433 & 0.169 \\
PSPTO4492 hypothetical protein & 2.049 & 0.040 \\
PSPTO4816 conserved hypothetical protein & 1.967 & 0.102 \\
PSPTO4931 hypothetical protein & 2.654 & 0.019 \\
PSPTO5228 hypothetical protein & 2.533 & 0.033 \\
PSPTO5365 conserved domain protein & 1.999 & 0.002 \\
PSPTO5613 conserved hypothetical protein & 2.025 & \\
\hline
\end{tabular}


bacterial actin homologue required for the maintenance of rodshaped cells (Carballido-Lopez et al. 2006); the induction of this gene may contribute to the elongation of $\mathrm{lon}^{-}$mutant cells (Bretz et al. 2002). Seventeen genes encoded hypothetical proteins or proteins of unknown function; some of these genes were clustered with genes of the above functional categories.

\section{Genes downregulated in the $\operatorname{lon}^{-}$mutant.}

A group of genes downregulated in the $\mathrm{lon}^{-}$mutant were related to cell membrane, including eight genes with putative functions in polysaccharide biogenesis (PSPTO0110, PSPTO0170, PSPTO0171, PSPTO0172, PSPTO1453, PSPTO2952, PSPTOA0030 and PSPTOA0032), three lipoproteins (PSPTO1507, PSPTO1634, and PSPTOA0031), and two inner-membrane and two outer-membrane proteins involved in transport (PSPTO0679, PSPTO1506, PSPTO2707, PSPTO5112). The reduction in polysaccharide biogenesis and membrane proteins may weaken the $\operatorname{lon}^{-}$mutant cell wall and, together with the elevated basic metabolism, this may contribute to the increased size and reduced fitness of $l^{-} n^{-}$mutant cells under stress conditions (Bretz et al. 2002). Alginate is the major exopolysaccharide of $P$. syringae bacteria; however, genes involved in alginate biosynthesis are not affected by $l^{-}$mutation. This is consistent with the notion that alginate biosynthesis is not affected in the lon mutant (Bretz et al. 2002).

Seven genes encoding putative metabolic enzymes were downregulated, in striking contrast to the large group of genes involved in energy metabolism that were induced in the lon $^{-} \mathrm{mu}-$ tant. Similarly, only two genes (PSPTO2310 and PSPTO4951) with a putative function in modulating protein synthesis were downregulated in the $l o n^{-}$mutant. These two proteins may negatively regulate the protein synthesis in $P$. syringae. Four genes (PSPTO0231, PSPTO1910, PSPTO3021, and PSPTO0853) with a potential transcriptional regulatory function were reduced in the lon $^{-}$mutant. The target genes regulated by these regulatory proteins are not known. In addition, a cluster of four genes en-

Table 3. Genes downregulated in the DC 3000 lon $^{-}$mutant

\begin{tabular}{|c|c|c|}
\hline PSPTO no. and description & WT-KB vs. lon ${ }^{-}-K B$ (fold) ${ }^{a}$ & $P$ value \\
\hline PSPTO3724 ATP-dependent protease Lon & 1.975 & 0.055 \\
\hline \multicolumn{3}{|l|}{ Cell wall-related (15) } \\
\hline PSPTO0110 metallo- $\beta$-lactamase superfamily protein & 1.463 & 0.072 \\
\hline PSPTO1070 lipopolysaccharide biosynthesis protein & 1.370 & 0.191 \\
\hline PSPTO1071 glycosyl transferase group 2 family protein & 1.376 & 0.076 \\
\hline PSPTO1072 aminotransferase DegT/DnrJ/EryC1/StrS family & 1.540 & 0.038 \\
\hline PSPTO1453 Levansucrase (EC 2.4.1.10) & 2.055 & 0.032 \\
\hline PSPTO2952 glycosidase, putative & 1.340 & 0.027 \\
\hline PSPTOA0030 glycosyl hydrolase family 25 & 1.475 & 0.154 \\
\hline PSPTOA0032 Levansucrase (EC 2.4.1.10) & 2.144 & 0.050 \\
\hline PSPTO1507 putative lipoprotein & 2.104 & 0.177 \\
\hline PSPTO1634 putative lipoprotein & 1.508 & 0.097 \\
\hline PSPTOA0031 putative lipoprotein & 1.571 & 0.012 \\
\hline PSPTO0679 outer membrane protein OmpW & 1.607 & 0.060 \\
\hline PSPTO1506 ompA family protein & 1.481 & 0.305 \\
\hline PSPTO2707 periplasmic mannitol-binding protein & 1.328 & 0.013 \\
\hline PSPTO5112 major facilitator superfamily protein & 1.325 & 0.025 \\
\hline \multicolumn{3}{|l|}{ Metabolism (7) } \\
\hline PSPTO0506 acyl-CoA dehydrogenase family protein & 1.380 & 0.132 \\
\hline PSPTO1126 amine oxidase flavin-containing & 1.436 & 0.021 \\
\hline PSPTO4168 glycerol kinase & 1.324 & 0.012 \\
\hline PSPTO4285 alcohol dehydrogenase II & 1.912 & 0.097 \\
\hline PSPTO5383 phosphoglycerate mutase family protein & 1.324 & 0.233 \\
\hline PSPTO4284 acetyltransferase GNAT family & 1.382 & 0.206 \\
\hline PSPTO5540 acyltransferase, putative & 1.320 & 0.102 \\
\hline \multicolumn{3}{|l|}{ Others (14) } \\
\hline PSPTO2310 ribosome modulation factor-related protein & 1.989 & 0.135 \\
\hline PSPTO4951 ribosome-associated GTPase & 1.336 & 0.043 \\
\hline PSPTO0231 DNA-binding protein inhibitor Id-2-related protein & 1.522 & 0.086 \\
\hline PSPTO1910 SH3 domain protein & 1.442 & 0.087 \\
\hline PSPTO3021 transcriptional regulator LysR family & 1.328 & 0.034 \\
\hline PSPTO0853 DksA, DNA repair and repress rRNA transcription & 1.970 & 0.107 \\
\hline PSPTO0576 Mu-like phage protein gp 38 & 1.392 & 0.096 \\
\hline PSPTO0577 tail sheath protein, putative & 1.349 & 0.114 \\
\hline PSPTO0578 phage tail tube protein & 1.364 & 0.061 \\
\hline PSPTO0579 prophage PSPPH01, putative tail protein & 1.358 & 0.312 \\
\hline PSPTO4770 UvrA domain & 1.328 & 0.040 \\
\hline \multicolumn{3}{|l|}{ Hypothetical and unknown functions (12) } \\
\hline PSPTO0221 HAD-superfamily hydrolase & 1.366 & 0.043 \\
\hline PSPTO0156 hypothetical protein & 2.095 & 0.213 \\
\hline PSPTO0507 Salt stress induced hydrophobic peptide & 2.539 & 0.341 \\
\hline PSPTO0854 hypothetical protein & 1.783 & 0.275 \\
\hline PSPTO1037 conserved hypothetical protein & 1.360 & 0.065 \\
\hline PSPTO1038 hypothetical protein & 1.459 & 0.153 \\
\hline PSPTO1635 ligand binding & 1.499 & 0.121 \\
\hline PSPTO4762 von Willebrand factor type A domain protein & 1.410 & 0.387 \\
\hline PSPTO4763 hypothetical protein & 1.326 & 0.029 \\
\hline PSPTO2057 hypothetical protein & 2.031 & 0.156 \\
\hline PSPTO5384 hypothetical protein & 1.482 & 0.020 \\
\hline PSPTOB0071 surface exclusion protein, putative & 1.396 & 0.069 \\
\hline
\end{tabular}

\footnotetext{
${ }^{\text {a }}$ The wild type (WT) treated with the rich medium King' B (KB) versus the $l o n^{-}$mutant treated with KB; numbers indicate the fold of induction in WT-KB.
} 
coding phage proteins also were repressed in the lon $^{-}$mutant. The DNA fragment harboring these genes likely is derived from a phage insertion.

Although the $P$. syringae lon $^{-}$mutant displayed increased sensitivity to UV irradiation, only two genes (PSPTO4770 and PSPTO0853) with an implicated function in DNA repair were downregulated in lon $^{-}$mutant. PSPTO4770 encodes a protein with the excision repair protein UvrA domain I. UvrA acts together with UvrB and UvrC proteins in nucleotide excision repair (Croteau et al. 2006). PSPTO0853 encodes the putative dnaK suppressor protein DksA. DksA is a stringent response regulator that plays a critical role in regulating bacterial gene expression. This gene also plays a critical role in transcriptioncoupled DNA repair (Meddows et al. 2005). Whether the reduced expression of these two genes is related to the increased UV sensitivity of the $\operatorname{lon}^{-}$mutant is not known. Nevertheless, other genes with known functions in DNA repair were not downregulated in the $\mathrm{lon}^{-}$mutant. Perhaps genes involved in DNA repair are induced upon UV irradiation in the WT strain and, here, the bacteria analyzed by the microarray were not exposed to UV irradiation.

Twelve genes were classified into the functionally unknown group, although sequence alignment identified conserved domains in several of these genes. A few of these genes were clustered with genes of the other functional categories and, thus, may have related functions. In addition, two pairs of functionally unknown genes were clustered in two genomic loci.

Expression of the HrpL-regulated genes in the $\mathrm{lon}^{-}$mutant.

Previous microarray analysis identified 112 DC3000 genes controlled by hrp box promoters and activated by $h r p L$ (Ferreira et al. 2006; Lan et al. 2006); 5 of them were not

Table 4. Expression of HrpL-regulated genes in $\operatorname{lon}^{-}$mutant

\begin{tabular}{|c|c|c|c|c|c|}
\hline PSPTO no. and description & $\begin{array}{c}\text { lon }^{-}-\mathrm{KB} \text { vs. } \\
\text { WT-KB }^{\mathrm{a}}\end{array}$ & $P$ value & $\begin{array}{l}\text { WT-MM vs. } \\
\text { lon }^{-}-K^{\mathbf{a}}\end{array}$ & $P$ value & Category $^{b}$ \\
\hline PSPTO1404 HrpL & 1.380 & 0.216 & 13.718 & 0.002 & \# \\
\hline PSPTOA0005 НорAM1-1 & 9.241 & 0.100 & 16.223 & 0.024 & 1 \\
\hline PSPTO1373 HrpW & 2.333 & 0.130 & 15.274 & 0.013 & 1 \\
\hline PSPTO1022 HopAM1-1 & 10.070 & 0.107 & 13.804 & 0.029 & 1 \\
\hline PSPTO1382 HrpZ & 3.281 & 0.160 & 8.486 & 0.009 & 1 \\
\hline PSPTO4776 HopPmaI & 1.955 & 0.096 & 6.413 & 0.007 & 1 \\
\hline PSPTO1381 HrpA & 5.271 & 0.117 & 6.238 & 0.004 & 1 \\
\hline PSPTO0589 HopC1 & 6.566 & 0.094 & 6.054 & 0.030 & 1 \\
\hline PSPTO4599 ShcS1 & 1.393 & 0.206 & 5.942 & 0.034 & $1 *$ \\
\hline PSPTO1383 HrpB & 1.895 & 0.180 & 5.483 & 0.068 & 1 \\
\hline PSPTO1399 HrpO & 1.563 & 0.242 & 5.032 & 0.015 & 1 \\
\hline PSPTO1387 HrpF & 2.648 & 0.131 & 4.925 & 0.008 & 1 \\
\hline PSPTO1369 ShcN & 3.154 & 0.073 & 4.595 & 0.015 & 1 \\
\hline PSPTO5353 SchA & 1.524 & 0.051 & 4.359 & 0.004 & 1 \\
\hline PSPTO0503 SchF & 2.461 & 0.145 & 4.344 & 0.086 & 1 \\
\hline PSPTOA0017 ShcO1 & 3.063 & 0.045 & 4.167 & 0.038 & 1 \\
\hline PSPTO1405 HrpK & 1.502 & 0.256 & 4.135 & 0.017 & 1 \\
\hline PSPTOA0018 HopO1-1 & 4.053 & 0.205 & 4.110 & 0.071 & 1 \\
\hline PSPTO0044 HopPtoK & 1.581 & 0.053 & 0.818 & 0.275 & 2 \\
\hline PSPTO0834 alcohol dehydrogenase zinc-containing & 4.141 & 0.115 & 0.563 & 0.311 & 2 \\
\hline PSPTO0835 ribD C-terminal domain protein & 3.084 & 0.058 & 1.060 & 0.852 & 2 \\
\hline PSPTO0836 conserved domain protein & 2.228 & 0.118 & 0.681 & 0.312 & 2 \\
\hline PSPTO0837 conserved hypothetical protein & 2.176 & 0.062 & 0.585 & 0.130 & 2 \\
\hline PSPTO0873 amidinotransferase family protein & 7.906 & 0.138 & 0.369 & 0.255 & $2 *$ \\
\hline PSPTO0874 nikkomycin biosynthesis domain protein & 2.270 & 0.111 & 0.787 & 0.450 & 2 \\
\hline PSPTO0875 Homolog of PSPTO0874 & 1.519 & 0.067 & 0.914 & 0.575 & 2 \\
\hline PSPTO4703 hopAQ1 & 2.385 & 0.193 & 0.522 & 0.267 & 2 \\
\hline PSPTO4101 HopAK1 & 1.360 & 0.141 & 3.727 & 0.003 & 3 \\
\hline PSPTO1384 HrcJ & 1.862 & 0.047 & 3.256 & 0.007 & 3 \\
\hline PSPTO3087 AvrPtoB & 1.971 & 0.176 & 3.187 & 0.019 & 3 \\
\hline PSPTO1389 HrcC & 1.604 & 0.118 & 3.040 & 0.010 & 3 \\
\hline PSPTO0588 НорH1 & 5.123 & 0.105 & 2.828 & 0.134 & 3 \\
\hline PSPTO1390 HrpT & 1.326 & 0.028 & 2.789 & 0.012 & 3 \\
\hline PSPTO4331 HopE1 & 6.864 & 0.082 & 2.757 & 0.053 & 3 \\
\hline PSPTO0061 HopY1 & 1.459 & 0.075 & 2.504 & 0.050 & 3 \\
\hline PSPTO1391 HrpV & 1.422 & 0.126 & 2.382 & 0.005 & 3 \\
\hline PSPTO1408 hypothetical protein & 2.088 & 0.114 & 1.919 & 0.074 & 3 \\
\hline PSPTO0371 indoleacetate-lysine ligase & 1.483 & 0.269 & 1.819 & 0.094 & 3 \\
\hline PSPTO4001 AvrPto & 7.819 & 0.081 & 1.620 & 0.235 & $3 *$ \\
\hline PSPTO1409 conserved hypothetical protein & 1.581 & 0.031 & 1.397 & 0.124 & 3 \\
\hline PSPTO0370 MATE efflux family protein & 0.909 & 0.772 & 0.979 & 0.937 & 4 \\
\hline PSPTO0473 hypothetical protein & 0.802 & 0.302 & 1.426 & 0.031 & 4 \\
\hline PSPTO0474 hypothetical protein & 0.821 & 0.266 & 1.338 & 0.171 & 4 \\
\hline PSPTO0501 type III effector HopPtoS2 & 0.898 & 0.680 & 1.070 & 0.768 & 4 \\
\hline PSPTO0502 type III effector HopPtoF & 0.948 & 0.628 & 1.247 & 0.092 & 4 \\
\hline PSPTO0524 peptidase, M20/M25/M40 family & 0.933 & 0.821 & 0.990 & 0.975 & 4 \\
\hline PSPTO0838 major facilitator family transporter & 1.129 & 0.456 & 0.841 & 0.170 & 4 \\
\hline PSPTO0851 conserved hypothetical protein & 0.920 & 0.509 & 1.388 & 0.082 & 4 \\
\hline PSPTO0852 HopAJ1 & 1.142 & 0.317 & 2.553 & 0.001 & 4 \\
\hline
\end{tabular}

\footnotetext{
${ }^{a}$ The lon $^{-}$mutant treated with the rich medium King' B (KB) versus the wild type (WT) treated with KB, and WT treated with minimal medium (MM) versus $l o n^{-}-\mathrm{KB}$; numbers indicate the fold of induction in the two comparisons.

${ }^{\mathrm{b}}$ Genes indicated by * were examined by Northern analysis; \# hrpL transcript level served as a reference. The last five genes were not present in the microarray.
} 
present in this microarray analysis. Of these genes, 39 were considered to be induced in the lon $^{-}$mutant, and the remaining 68 genes displayed minor or no induction (Table 4). Microarray and Northern blot analyses indicated that the $h r p L$ RNA, even though elevated in the lon mutant compared with the WT strain in KB (WT-KB), still was much less abundant than seen in WT treated with MM (WT-MM) (Fig. 2A). This observation triggered us to compare the RNA levels of the HrpL-regulated genes in WT-MM and in the lon $^{-}$mutant treated with $\mathrm{KB}\left(\mathrm{lon}^{-}-\mathrm{KB}\right)$ to determine whether there is a correlation between $h r p L$ RNA abundance and the levels of hrp box gene expression.

Comparison of the microarray hybridization signals between WT-MM and $l o n^{-}-\mathrm{KB}$ indicated that the hrpL RNA was 13.7fold higher in WT-MM than in lon $^{-}-\mathrm{KB}$, but the HrpL-regulated genes displayed a range of 0.37 - to 16.2-fold difference in RNA abundance (Table 4). The HrpL-regulated genes could be divided into four groups according to their gene expression patterns (Table 4).

Genes in the first group were induced in $l^{-} n^{-} \mathrm{KB}$ versus WT$\mathrm{KB}$, and their RNA abundance in WT-MM and in lon $^{-}-\mathrm{KB}$ correlated well with the abundance of $h r p L$ RNA (4- to 16.2-fold difference versus 13.7-fold for $h r p L$ ). Compared with the hrp box genes that are not induced or poorly induced in $l o n^{-}-\mathrm{KB}$, these genes probably have a stronger promoter with high HrpLbinding affinity. Thus, a low level of HrpL in $l o n^{-}-\mathrm{KB}$ is sufficient to activate these genes. These genes can be further induced with the increasing level of HrpL in WT-MM. This is consistent with our observation that $\mathrm{HrpL}$, when overexpressed in $P$. syringae, strongly induces the hrp box genes (data not shown). It is worthwhile to note that HrpL may not be the only factor controlling the high levels of expression of the group 1 genes in WT-

Table 4. (continued from preceding page)

\begin{tabular}{|c|c|c|c|c|c|}
\hline PSPTO no. and description & $\begin{array}{c}\text { lon }^{-}-\mathrm{KB} \text { vs. } \\
\text { WT-KB }^{\mathbf{a}}\end{array}$ & $P$ value & $\begin{array}{l}\text { WT-MM vs. } \\
\text { lon }^{-}-K^{\mathbf{a}}\end{array}$ & $P$ value & Category $^{b}$ \\
\hline PSPTO0876 HopD1 & 1.170 & 0.208 & 3.382 & 0.005 & 4 \\
\hline PSPTO0877 HopQ1-1 & 1.288 & 0.128 & 6.105 & 0.041 & 4 \\
\hline PSPTO0883 HopR1 & 1.084 & 0.824 & 1.463 & 0.139 & 4 \\
\hline PSPTO0901 & 0.962 & 0.827 & 1.078 & 0.628 & 4 \\
\hline PSPTO1370 HopN1 & 1.305 & 0.320 & 4.557 & 0.004 & 4 \\
\hline PSPTO1372 HopPtoA1 & 0.837 & 0.554 & 1.729 & 0.023 & 4 \\
\hline PSPTO1374 ShcM & 1.093 & 0.427 & 5.700 & 0.022 & 4 \\
\hline PSPTO1375 HopM1 & 1.098 & 0.610 & 4.528 & 0.002 & 4 \\
\hline PSPTO1376 type III chaperone candidate protein & 0.895 & 0.311 & 1.590 & 0.007 & 4 \\
\hline PSPTO1377 AvrE & 0.939 & 0.485 & 1.858 & 0.000 & 4 \\
\hline PSPTO1378 membrane-bound lytic murein transglycosylase D, putative & 0.881 & 0.540 & 1.436 & 0.104 & 4 \\
\hline PSPTO1385 HrpD & 1.198 & 0.293 & 2.113 & 0.003 & 4 \\
\hline PSPTO1386 HrpE & 0.917 & 0.789 & 2.090 & 0.059 & 4 \\
\hline PSPTO1388 HrpG & 1.123 & 0.498 & 2.708 & 0.045 & 4 \\
\hline PSPTO1392 HrcU & 0.863 & 0.611 & 1.311 & 0.308 & 4 \\
\hline PSPTO1393 HrcT & 0.911 & 0.814 & 1.208 & 0.561 & 4 \\
\hline PSPTO1394 HrcS & 0.865 & 0.751 & 1.123 & 0.756 & 4 \\
\hline PSPTO1395 HrcR & 1.020 & 0.928 & 1.860 & 0.045 & 4 \\
\hline PSPTO1396 HrcQb & 1.123 & 0.657 & 2.218 & 0.003 & 4 \\
\hline PSPTO1397 HrcQa & 0.984 & 0.904 & 2.051 & 0.007 & 4 \\
\hline PSPTO1398 HrpP & 0.925 & 0.289 & 1.805 & 0.000 & 4 \\
\hline PSPTO1400 HrcN & 0.841 & 0.650 & 1.866 & 0.042 & 4 \\
\hline PSPTO1401 HrpQ & 1.031 & 0.822 & 2.121 & 0.001 & 4 \\
\hline PSPTO1402 HrcV & 1.028 & 0.949 & 1.686 & 0.124 & 4 \\
\hline PSPTO1403 HrpJ & 0.865 & 0.589 & 2.721 & 0.001 & 4 \\
\hline PSPTO1406 НорB1 & 1.319 & 0.163 & 5.752 & 0.010 & 4 \\
\hline PSPTO1568 HopPtoJ & 1.210 & 0.206 & 0.941 & 0.671 & 4 \\
\hline PSPTO1645 transcriptional regulator, MarR family & 0.867 & 0.066 & 1.426 & 0.004 & 4 \\
\hline PSPTO2105 thiamine biosynthesis lipoprotein & 1.009 & 0.949 & 1.407 & 0.034 & 4 \\
\hline PSPTO2678 HopP1 & 1.197 & 0.357 & 3.173 & 0.002 & 4 \\
\hline PSPTO2679 hypothetical protein & 0.953 & 0.393 & 2.299 & 0.013 & 4 \\
\hline PSPTO2691 membrane protein TerC family & 1.056 & 0.766 & 1.727 & 0.010 & 4 \\
\hline PSPTO4588 HopS2 & 1.011 & 0.934 & 2.512 & 0.003 & 4 \\
\hline PSPTO4589 ShcS2 & 0.973 & 0.815 & 11.959 & 0.022 & 4 \\
\hline PSPTO4597 HopS1 & 1.224 & 0.111 & 5.491 & 0.004 & 4 \\
\hline PSPTO4691 HopAD1 & 0.914 & 0.439 & 1.809 & 0.005 & 4 \\
\hline PSPTO4718 type III effector HopPtoA2 & 0.966 & 0.942 & 1.522 & 0.364 & 4 \\
\hline PSPTO4720 HopV1 & 1.119 & 0.217 & 3.986 & 0.002 & 4 \\
\hline PSPTO4721 ShcV & 1.188 & 0.385 & 6.080 & 0.021 & 4 \\
\hline PSPTO4722 HopAO1 & 1.018 & 0.851 & 1.716 & 0.012 & 4 \\
\hline PSPTO4727 HopG1 & 0.891 & 0.524 & 6.998 & 0.104 & 4 \\
\hline PSPTO4732 HopQ1-2 & 1.045 & 0.726 & 1.586 & 0.023 & 4 \\
\hline PSPTO4733 hypothetical protein & 1.195 & 0.310 & 2.003 & 0.051 & 4 \\
\hline PSPTO5354 HopA1 & 1.118 & 0.297 & 5.901 & 0.029 & 4 \\
\hline PSPTO5355 hypothetical protein & 1.009 & 0.947 & 1.433 & 0.023 & 4 \\
\hline PSPTOA0012 HopX1 & 0.931 & 0.691 & 3.149 & 0.004 & 4 \\
\hline PSPTOA0019 НорT1-1 & 1.311 & 0.117 & 3.403 & 0.017 & 4 \\
\hline PSPTOB0005 phosphoesterase family protein & 1.182 & 0.227 & 4.061 & 0.007 & 4 \\
\hline PSPTO5616 & $\ldots$ & $\ldots$ & $\ldots$ & $\ldots$ & $\ldots$ \\
\hline PSPTO5617 & $\ldots$ & $\ldots$ & $\ldots$ & $\ldots$ & $\ldots$ \\
\hline PSPTO5619 & $\ldots$ & $\ldots$ & $\ldots$ & $\ldots$ & $\ldots$ \\
\hline PSPTO5620 & $\ldots$ & $\ldots$ & $\ldots$ & $\ldots$ & $\ldots$ \\
\hline PSPTOB0078 & $\ldots$ & $\ldots$ & $\ldots$ & $\ldots$ & $\ldots$ \\
\hline
\end{tabular}


MM. Other mechanisms regulating either gene transcription or RNA stability may differ between WT-MM and $l^{-} n^{-}-\mathrm{KB}$ and contribute to the differential induction. For instance, either a positive regulator present in WT-MM but absent in lon $^{-}-\mathrm{KB}$ or a negative regulator present in $l o n^{-}-\mathrm{KB}$ but absent in WT-MM would lead to the high induction of these hrp box genes in WTMM.

The second group contained nine genes that accumulated the same or more RNA in $l^{-} n^{-}$KB than in WT-MM. In addition to $\mathrm{HrpL}$, the expression of these genes likely involves a second regulator that functions either positively in $l^{-}{ }^{-}-\mathrm{KB}$ or negatively in WT-MM. Only four HrpL-regulated loci (PSPTO0873-0874-0875, PSPTO0834-0835-0836-0837, PSPTO0044, and PSPTO4703) displayed this type of expression pattern. The first two loci encode metabolic enzymes with predicted roles in secondary metabolism. It was reported that lon mutation elevates antibiotic production in $P$. fluorescens (Whistler et al. 2000). Whether these two loci are involved in antibiotic production in DC3000 remains to be determined.

The group 3 genes were induced in $l o n^{-}-\mathrm{KB}$ versus WT-KB, but the RNA abundance in WT-MM was less than fourfold higher than in $l^{-} n^{-} \mathrm{KB}$. The promoters of these genes may have a very high affinity for HrpL; thus, a small amount of HrpL is sufficient for maximal induction of these genes in $l o n^{-}$ -KB. As such, these genes might be the early genes during the TTSS induction when the hrpL level is still low. Alternatively, the induction of genes in group 3, similar to genes of group 2, also may involve a second regulator that is differentially present in $l^{-}{ }^{-}-\mathrm{KB}$ and WT-MM.

All 68 HrpL-regulated genes that display poor or no induction in $l o n^{-}-\mathrm{KB}$ versus WT-KB belong to group 4. In general, genes in this group that display a minor induction in $l o n^{-}-\mathrm{KB}$ versus WT-KB also display relatively higher HrpL-dependent induction in $\mathrm{MM}$, whereas genes that display no induction in lon $^{-}$-KB versus WT-KB also display relatively lower HrpLdependent induction in MM. Perhaps the promoters of these genes are weak, and the low level of HrpL in $l^{-} n^{-} \mathrm{KB}$ is insufficient to activate these genes to a level significantly above the control. However we cannot rule out the involvement of other regulators that are differentially present in WT$\mathrm{MM}$ and $l^{-} n^{-}-\mathrm{KB}$. Genes representing the first three groups (PSPTO4599 for group 1, PSPTO0873 for group 2, and

A

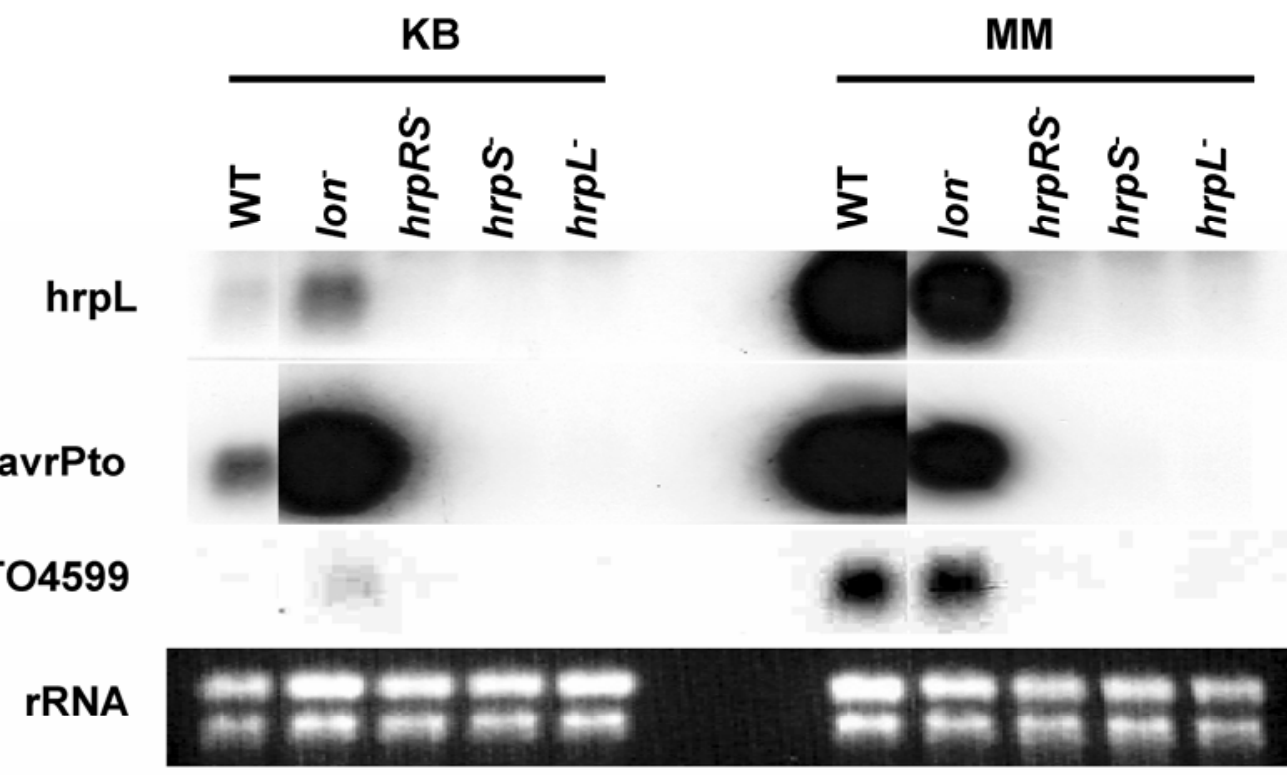

B

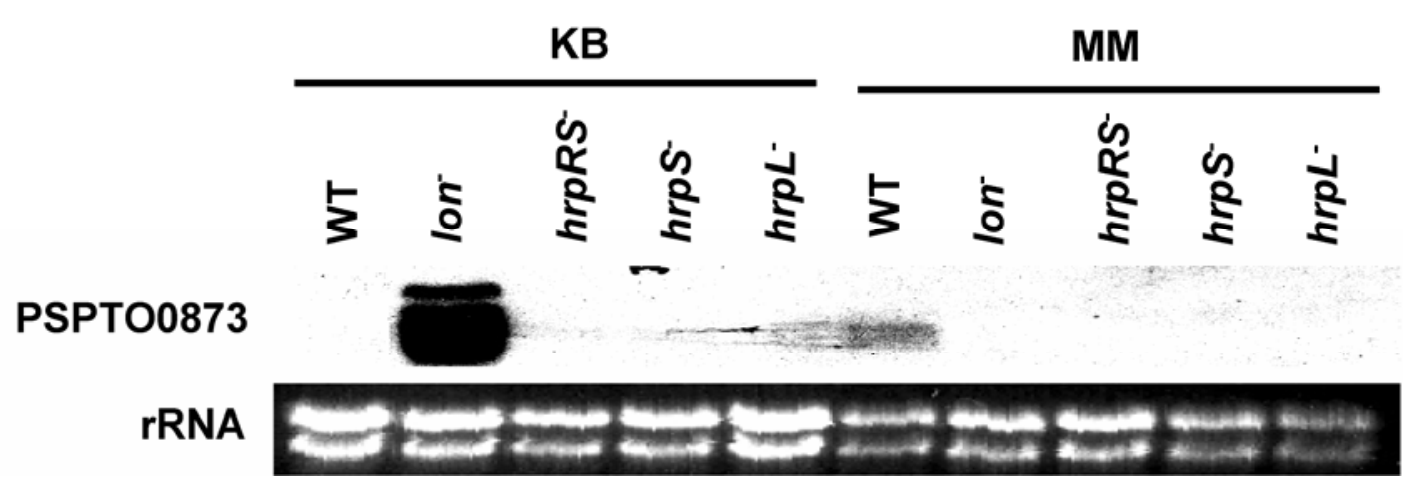

Fig. 2. Northern blot analysis of $h r p L$ and three HrpL-regulated genes in the wild-type (WT) DC3000 and the derived $l o n^{-}, h r p R S^{-}, h r p S^{-}$, and $h r p L^{-}$mutants in rich medium King's B (KB) and minimal medium (MM). The bacteria were cultured in KB to an optical density at $600 \mathrm{~nm}\left(\mathrm{OD}_{600}\right)$ of 0.7 to 0.8 before harvesting for RNA extraction. For the test in MM, the bacteria first were cultured in $\mathrm{KB}$ to $\mathrm{OD}_{600}=0.7$ to 0.8 and then washed twice with MM, resuspended in $\mathrm{MM}$ to $\mathrm{OD}_{600}=0.2$, and cultured for another $6 \mathrm{~h}$ before being harvested for RNA extraction. The coding region of each gene was polymerase chain reaction (PCR) amplified and radiolabeled with ${ }^{32} \mathrm{P}-\mathrm{dCTP}$ for probes. A, All the genes were tested with the same RNA samples. The composite bands for each probe were from the same hybridization and autoradiography. B, The test was conducted with a different set of RNA samples. The ethidium bromidestained gel pictures in each panel indicate the loading of the RNA samples. 
avrPto for group 3) were analyzed by Northern blotting, and they showed the same expression patterns as indicated by the microarray (Fig. 2A and B).

The $l o n^{-}$mutation differently affects the expression of the TTSS regulatory genes in KB and MM.

It is known that the ${ }^{-} n^{-}$mutation allows stabilization of HrpR, which in turn activates hrpL in rich medium. To determine whether the $l o n^{-}$mutation similarly impacts $h r p L$ expression in MM, we conducted Northern blot analysis to compare the hrpL RNA in the WT DC3000 strain and the lon mutant cultured in $\mathrm{KB}$ and $\mathrm{MM}$ (Fig. 2A). In $\mathrm{KB}$, the lon $^{-}$mutant showed more hrpL RNA than did the WT strain. Unexpectedly, the lon $^{-}$mutant displayed lower $h r p L$ RNA than did the WT strain after $6 \mathrm{~h}$ of growth in MM. To determine whether this is a general phenomenon, three $P$. syringae pv. phaseolicola lon mutants were similarly tested, and all exhibited similar results (Fig. 3A and B). The reduced hrpL RNA in the $l o n^{-}$mutants was unexpected, because $l o n^{-}$mutation stabilizes HrpR which, in turn, would induce more $h r p L$ expression. This also was different from an earlier report that the DC3000 lon $^{-}$mutant displayed a higher level of $h r p L$ expression by $30 \mathrm{~min}$ after induction in MM (Bretz et al. 2002). To further investigate $h r p L$ expression in $\mathrm{MM}$, we determined the dynamics of $h r p L$ expression in $l^{-}{ }^{-}$MM (Fig. 3C). The hrpL RNA in the lon ${ }^{-}$mutant was induced to a high level $1 \mathrm{~h}$ after culture in MM and then decreased. In con-
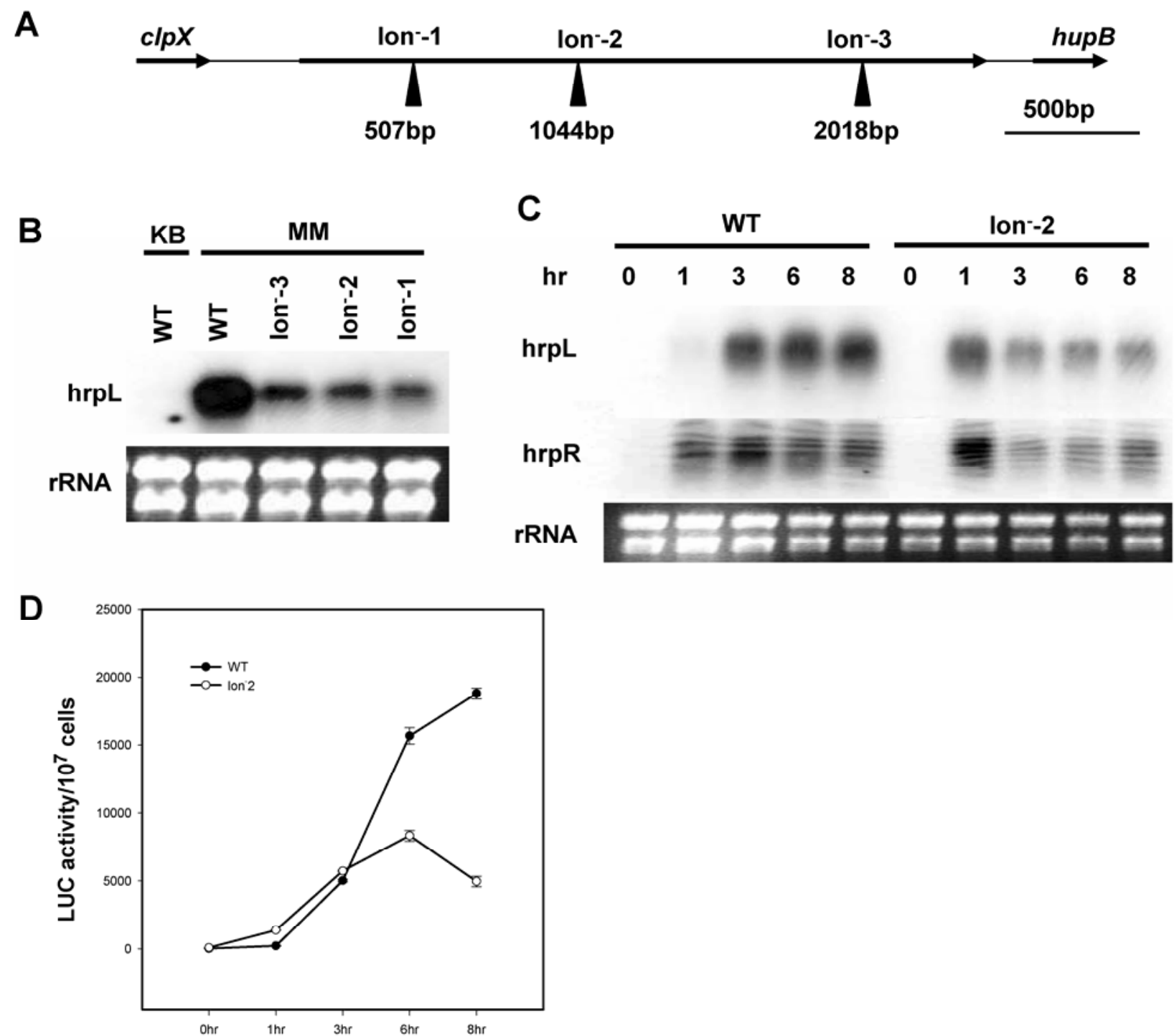

Time after induction in MM

Fig. 3. Mutation of lon affects the expression of $h r p L$ differently in rich medium King's B (KB) and minimal medium (MM). A, Three lon ${ }^{-}$mutants of $P s e u-$ domonas syringae pv. phaseolicola NPS3121 strain. The long arrow indicates the open reading frame of lon. Three triangles underneath indicate the transposon insertion sites. The numbers represent insertion locations relative to the start codon. B, The $h r p L$ RNA expression in the lon mutants. The bacteria were cultured in $\mathrm{KB}$ to an optical density at $600 \mathrm{~nm}\left(\mathrm{OD}_{600}\right)$ of 0.7 to 0.8 before harvesting for RNA extraction. For the test in MM, the bacteria first were cultured in $\mathrm{KB}$ to $\mathrm{OD}_{600}=0.7$ to 0.8 and then washed twice with $\mathrm{MM}$, resuspended in $\mathrm{MM}$ to $\mathrm{OD}_{600}=0.2$, and cultured for another $6 \mathrm{~h}$ before being harvested for RNA extraction. The $h r p L$ coding region was polymerase chain reaction (PCR) amplified and radiolabeled with ${ }^{32} \mathrm{P}$-dCTP as probes. The ethidium bromide gel picture shows the loading of RNA samples. C, Comparison of the $h r p L$ and $h r p R$ expression dynamics in MM. The wild-type (WT) NPS3121 strain and the derived $l o n^{-}-2$ mutant were cultured in KB to an optical density at $600 \mathrm{~nm}$ of 0.7 to 0.8 before induction in MM as described in B. Bacteria were harvested after 1, 3, 6, and $8 \mathrm{~h}$ in MM; " 0 " indicated bacteria before treatment with MM. The coding regions of $h r p L$ and $h r p R$ were PCR amplified and radiolabeled with ${ }^{32} \mathrm{P}$-dCTP as probes. The loading of RNA samples is indicated by the ethidium bromide-stained gel. D, Analysis of $h r p L$ promoter activity in the NPS3121 WT strain and the lon mutants. The hrpL-luc reporter gene constructed by Xiao and associates (2004) was introduced in the NPS3121 WT strain and the $l^{-} n^{-}-2$ mutant. Bacteria were cultured in KB and MM as described in B. The luciferase (LUC) activity was measured by mixing $1 \mu$ of $1 \mathrm{mM}$ luciferin with $100 \mu \mathrm{l}$ of cultured cells $\left(2 \times 10^{7} \mathrm{CFU}\right)$ in MM, and the LUC activity was measured at the indicated times. 
trast, in the WT strain, the induction of hrpL RNA was delayed. A strong signal was detected approximately $3 \mathrm{~h}$ after induction in MM, and it remained high until $8 \mathrm{~h}$. A further test with the hrpL-LUC reporter showed that LUC activity was higher in the lon $^{-}$mutant than in the WT strain within $1 \mathrm{~h}$. The LUC activity in the WT strain continued to increase while the LUC activity in the $l^{-} n^{-}$mutant decreased after $6 \mathrm{~h}$ (Fig. 3D). Compared with the hrpL RNA abundance, the peak of LUC activity in both strains was much delayed; this probably is due to stability of the LUC protein.

To determine whether reduced $h r p L$ expression resulted from reduced expression of upstream regulators, we examined the RNAs of $h r p R, h r p S, \operatorname{rpoN}, g a c A$, and $\operatorname{rhpS}$ in the lon

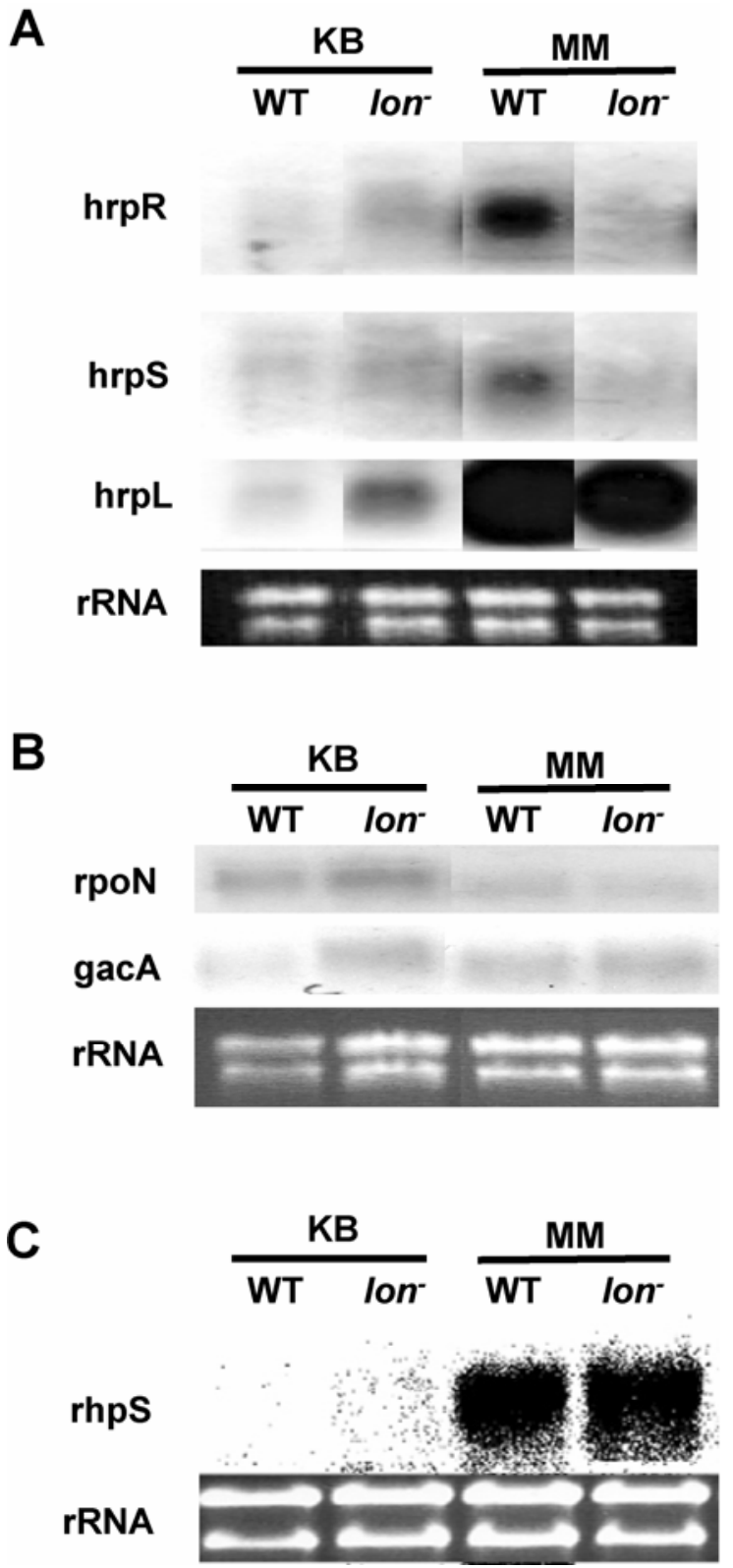

Fig. 4. Expression of type III secretion system regulatory genes in wildtype (WT) DC3000 and the lon ${ }^{-}$mutant in rich medium King's B (KB) and minimal medium (MM). Bacteria were grown in $\mathrm{KB}$ and induced in $\mathrm{MM}$ for $6 \mathrm{~h}$. The coding region of each gene was polymerase chain reaction (PCR) amplified and radiolabeled with ${ }^{32} \mathrm{P}$-dCTP as probes. A, Expression of $h r p R$, $h r p S$, and $h r p L$ genes. B, Expression of gacA and $r p o N$ genes. C, Expression of the rhpS gene. The composite bands for each probe were from the same hybridization and autoradiography. Loading of the RNA samples is indicated by the ethidium bromide gels. mutant and WT DC3000 strains. GacA is a two-component response regulator that is coupled with the sensor kinase GacS to regulate a variety of traits in bacteria (Heeb and Haas 2001). This system controls expression of TTSS genes through the hrpRS-hrpL regulatory cascade in $P$. syringae pv. tomato strain DC3000. GacA deficiency attenuates the transcription levels of $h r p R S, r p o N$, and $h r p L$ significantly (Chatterjee et al. 2003). RhpS is a sensor kinase that recently was found to control induction of the TTSS genes in MM and in planta. Mutation of $r h p S$ severely diminishes induction of $h r p L$ and $h r p R S$ (Xiao et al. 2007). In KB, disruption of lon marginally increases the RNAs of hrpR, hrpS, rpoN, gacA, and $r h p S$. After $6 \mathrm{~h}$ of growth in MM, the lon $^{-}$mutation did not affect the $r p o N$, gacA, and $\operatorname{rhpS}$ RNAs, but it significantly reduced the $h r p R$ and $h r p S$ RNAs (Fig. 4). The time course study in Figure $3 \mathrm{C}$ indicated that the level of $h r p R$ RNA is well correlated with the $h r p L$ RNA in the $l o n^{-}$ mutant. This result suggested that Lon acts as a positive regulator for the $P$. syringae TTSS genes in MM. Positive regulation of TTSS genes by Lon was reported in Yersinia spp. Lon mediates the degradation of YmoA, a histone-like protein that represses expression of LcrF, the positive regulator of the Yersinia TTSS genes. The YmoA protein accumulates in the absence of Lon which, in turn, represses the TTSS genes (Jackson et al. 2004). Similarly, P. syringae may have a negative regulator repressing the $h r p R S$ operon in $\mathrm{MM}$, and this negative regulator might be degraded by Lon. If this is true, the negative regulator would accumulate and repress the hrpRS operon in the $l^{-} n^{-}$mutant. Because HrpR, but not HrpS, can be degraded by Lon (Bretz et al. 2002), the $l n^{-}$mutation would allow the buildup of HrpR but not HrpS in the mutant. In this scenario, reduced HrpS may account for the reduced $h r p L$ expression in the $l o n^{-}-\mathrm{MM}$.

\section{Mutation of lon reduces the pathogenicity \\ of $P$. syringae on host plants.}

The lon $^{-}$mutants of the $P$. syringae pv. syringae 61 strain and the $P$. syringae pv. tomato DC3000 strain both were reported to elicit a more rapid hypersensitive response than did the corresponding WT strains on the nonhost tobacco plants; however, the DC3000 lon mutant did not affect the pathogenicity on Arabidopsis plants (Bretz et al. 2002). The stronger HR was proposed to be attributed to the stabilization and heightened secretion of effectors in the $l^{-}$mutants (Losada and Hutcheson 2005). Our Northern blot analysis indicated a reduced expression of the TTSS genes in the lon $^{-}$ mutant in MM. Reduction of the TTSS genes under TTSSinducing conditions may lead to reduced pathogenicity of the $l{ }^{-} n^{-}$mutant. To test this possibility, $l o n^{-}$mutants of $P$. syringae pv. phaseolicola and $P$. syringae pv. tomato strains were inoculated on bean and tomato plants, respectively. In several repeat experiments, both mutants consistently produced fewer symptoms and exhibited less growth than did their corresponding WT strains (Fig. 5A through D and Supplementary Fig. 1). Although the growth of the P. syringae pv. phaseolicola lon $^{-}$mutants was reduced by only 2.5 - to 3.5 -fold, the reduction was oberved in all repeat experiments, and statistical analysis indicated that this reduction was significant. Expression of a plasmid-borne lon gene largely complements the defect in pathogenicity. These data indicated that lon is required for full pathogenicity of $P$. syringae. The reduced pathogenicity is consistent with reduced TTSS gene expression in $l o n^{-}$mutants. However, because the $l o n^{-}$mutation is pleiotropic, the effect on the TTSS-independent genes also may contribute to the reduced pathogenicity. The discrepancy between our observation and that of Bretz and associates (2002) may result from the use of different host plants or dif- 
ferent concentrations of bacteria for inoculation. The requirement of lon for full pathogenicity also was reported in many other bacterial strains such as Salmonella enterica (Takaya et al. 2005), A. tumefaciens (Su et al. 2006), and Brucella abortus (Robertson et al. 2000).

\section{MATERIALS AND METHODS}

Plant materials and bacterial strains.

Bean (Phaseolus vulgaris cv. Red Kidney) and tomato (Lycopersicon esculentum cv. Rio-Grande PtoS) plants were

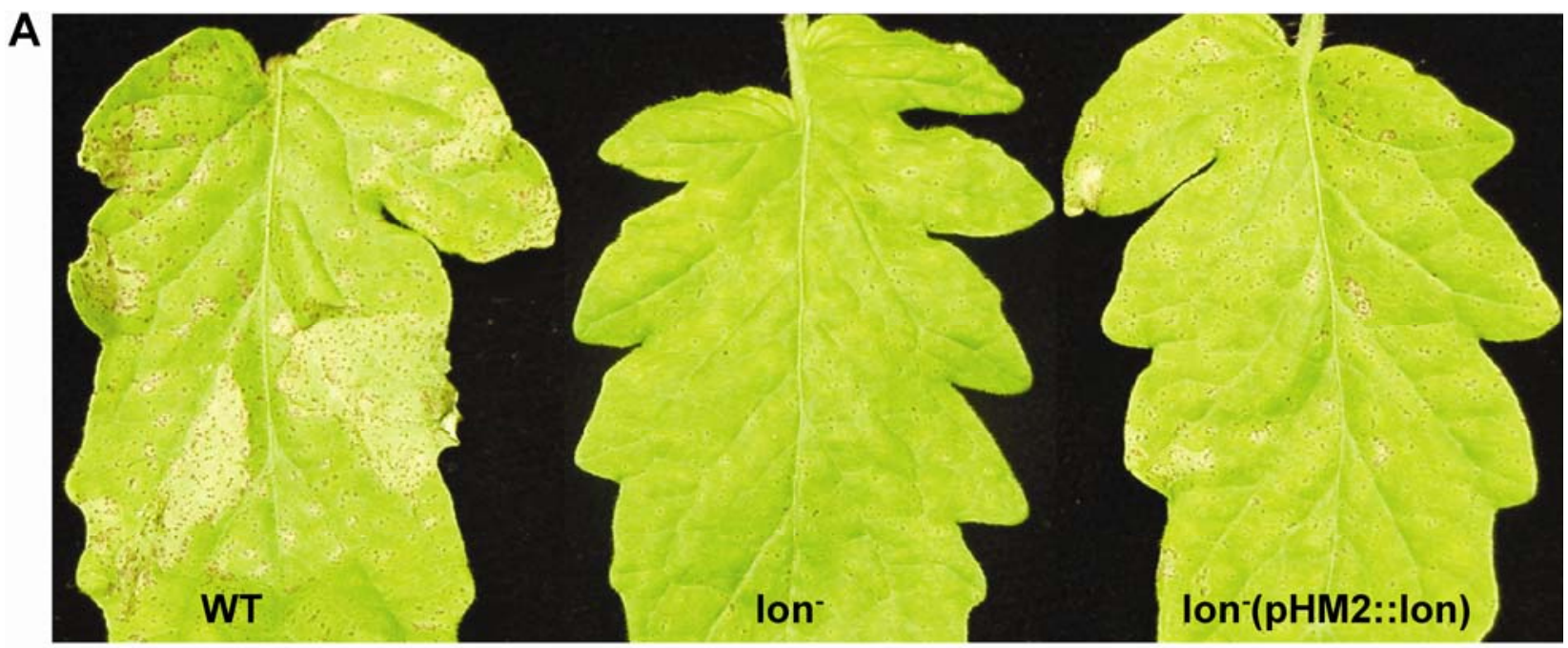

B
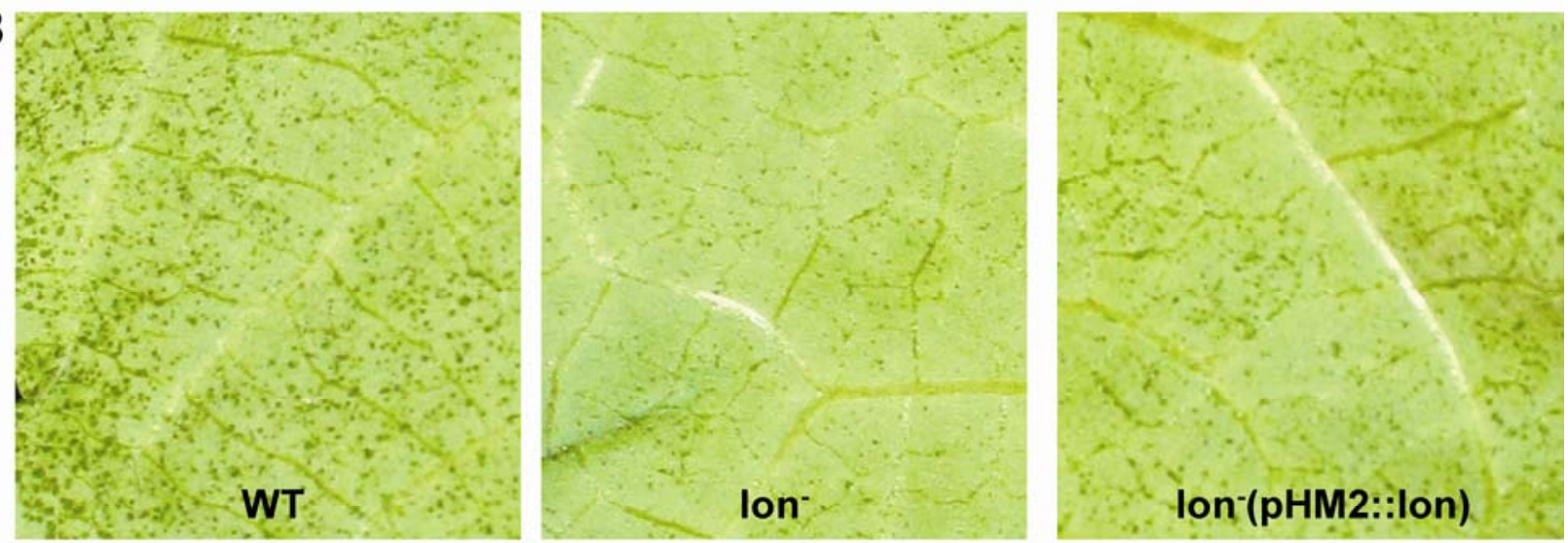

C
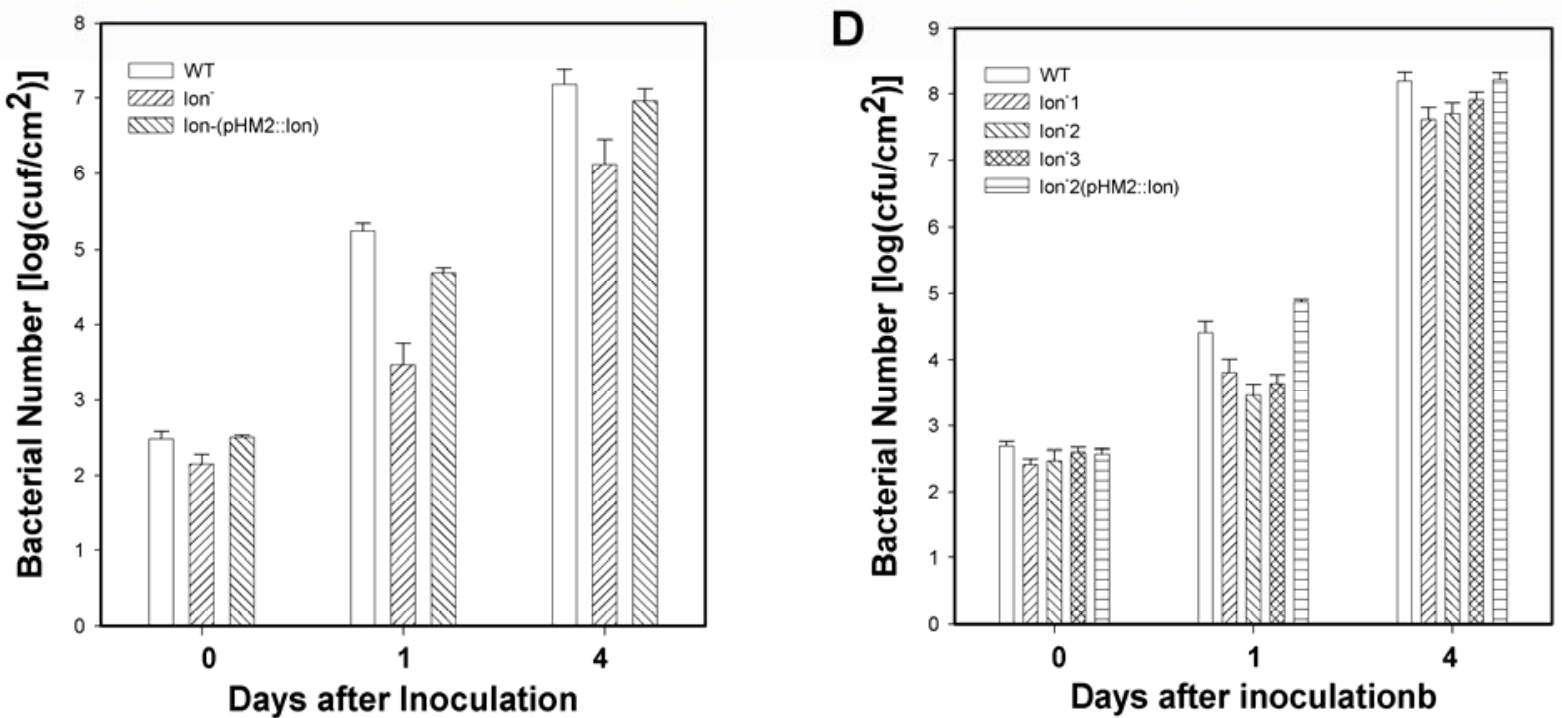

Fig. 5. Pathogenicity assay of the $l o n^{-}$mutants derived from strains DC3000 and NPS3121. The wild-type (WT), lon ${ }^{-}$mutant, and complemented lon mutant strains were grown in rich medium King's B to an optical density at $600 \mathrm{~nm}$ of 2.0 to 3.0, washed twice with sterile water, and resuspended in water (plus silwet L-77 at $10 \mu \mathrm{l} /$ liter for DC3000 and its derived strains) to the final concentration of $2 \times 10^{4} \mathrm{CFU} / \mathrm{ml}$ for inoculation. The bacteria were vacuum infiltrated into tomato and syringe infiltrated into bean primary leaves. The disease symptoms on $\mathbf{A}$, tomato and $\mathbf{B}$, bean leaves were photographed at 5 days after inoculation. Representative leaf areas from the inoculated bean leaf were $\times 3$ magnified to show the disease lesions (B). Bacterial populations in $\mathbf{C}$, tomato and $\mathbf{D}$, bean leaves were measured at the indicated times. The error bars indicate standard error. 
grown in a greenhouse and used for pathogenicity assays. Bacterial strains used in this study were Pseudomonas syringae pv. tomato DC3000 and P. syringae pv. phaseolicola NPS3121 and the $l^{-} n^{-}$mutant strains derived from them. The DC3000 lon $^{-}$mutant was isolated by screening a DC3000 Tn5<TET-1 $>$ transposon insertion mutant library by nested polymerase chain reaction (PCR) following the procedures described by Xiao and associates (2007). Two lon gene-based primers, $l o n^{-} 1-\mathrm{G} 1$ and $l o n^{-} 1-\mathrm{G} 2$, and two transposon-based primers, TN-Tet-L1 and TN-Tet-L2 (Table 5), were used for nested PCR. The mutant carried the Tn5<TET-1> transposon inserted at 1,691 bp downstream of the translation initiation site. The three NPS3121 lon ${ }^{-}$mutants were identified from an $\mathrm{EZ}-\mathrm{Tn}^{\mathrm{KM}}<\mathrm{Kan}-2>$ transposon insertion mutant library by screening for mutants with high levels of avrPto-luc expression in the KB medium. The transposon insertion sites were determined using a two-stage semidegenerated PCR according to Xiao and associates (2007). Transposons were inserted at 507, 1,044, and 2,018 bp downstream from the translation initiation site. Southern blot analysis indicated that all mutants carried a single-copy transposon insertion (data not shown). The KB medium (per liter) contained $29 \mathrm{~g}$ of Bacto proteose peptone, $1.5 \mathrm{~g}$ of $\mathrm{K}_{2} \mathrm{HPO}_{4}, 8 \mathrm{ml}$ of glycerol, and $0.74 \mathrm{~g}$ of $\mathrm{MgSO}_{4}$. The $\mathrm{MM}$ (per litter) contained $6.8 \mathrm{~g}$ of $\mathrm{KH}_{2} \mathrm{PO}_{4}, 1 \mathrm{~g}$ of $\left(\mathrm{NH}_{4}\right)_{2} \mathrm{SO}_{4}, 345 \mathrm{mg}$ of $\mathrm{MgCl}_{2} \cdot 6 \mathrm{H}_{2} \mathrm{O}, 100$ $\mathrm{mg}$ of $\mathrm{NaCl}$, and $1.8 \mathrm{~g}$ of fructose. The $\mathrm{pH}$ was adjusted to 5.7 with $\mathrm{KOH}$.

\section{Microarray design and analysis.}

A high-density oligonucleotide array was designed to cover 5,608 predicted ORF of DC3000. Each probe pair had a perfect-match oligonucleotide of 24 nucleotides and a mismatch oligonucleotide of the same sequence except substitutions at positions 6 and 12. The substitutions were A to T, C to $\mathrm{G}, \mathrm{G}$ to $\mathrm{C}$, and $\mathrm{T}$ to $\mathrm{A}$. Seventeen distinct high-quality probe pairs were designed for each ORF. The synthesis of cDNA probes and microarray hybridization, washing, and staining were performed by NimbleGen Systems Inc. (Madison, WI, U.S.A.) according to the standard protocol. Arrays were scanned with an Axon Genepix 4000B scanner at 532 $\mathrm{nm}$ and a resolution of $5 \mu \mathrm{m}$.
Microarray data analysis.

For each probe on the array, the median signal intensity was calculated using the NimbleGen extraction software. The data were normalized by using quantile normalization (Bolstad et al. 2003), and gene calls were generated by using the robust multichip average algorithm (Irizarry et al. 2003). The relative fluorescent intensities of each ORF were scaled by assuming a constant mean signal intensity of 1,000 signal units for each array, and the intensity values of replicate measurements were averaged. For each pairwise sample comparison, $P$ values were calculated for each ORF using the two-sided $t$ test.

\section{RNA isolation and Northern blotting.}

The bacterial strains were grown in KB broth (King et al. 1954) to approximately $7 \times 10^{8} \mathrm{CFU} / \mathrm{ml}$ before being harvested for RNA extraction. For gene expression analysis in MM, the bacteria first were grown in $\mathrm{KB}$ to $1 \times 10^{9} \mathrm{CFU} / \mathrm{ml}$, then centrifuged, washed twice with MM (Huynh et al. 1989), resuspended in $\mathrm{MM}$ to $3 \times 10^{8} \mathrm{CFU} / \mathrm{ml}$, and cultured for different periods before RNA extraction. Procedures described by Lan and associates (2006) were used for RNA extraction and Northern blotting.

\section{Construction of the pHM2::Ion for complementation.}

The NPS3121 lon gene under the native promoter (210 bases upstream of the ORF) was PCR amplified using the primers 5'-TTAAGCTTCACACGCAGGTGTATGGG-3' (containing HindIII) and 5'-CTAGCTAGCATGCGTGCTAATTCTGTC-3' (containing NheI). The PCR product was digested with HindIII and NheI and cloned into the pBS-HA vector (X. Deng, unpublished). After sequence verification, the insert was released with HindIII and BamHI and cloned into pHM2 (Xiao et al. 2007).

\section{Bacterial growth and disease symptoms assays.}

Preparation of bacterial inoculum and the bacterial growth assay were performed as described by Shan and associates (2000). NSP3121 at $2 \times 10^{4} \mathrm{CFU} / \mathrm{ml}$ was hand injected into the fully expended primary leaves of bean plants 10 days after emerging from soil. DC3000 at $2 \times 10^{4} \mathrm{CFU} / \mathrm{ml}$ was vacuum infiltrated into tomato plants 3 weeks after emergence from

Table 5. Polymerase chain reaction (PCR) primers used in this study

\begin{tabular}{|c|c|c|}
\hline Primers & Forward & Reverse \\
\hline PSPTO4224 & AACCCAGGAAGAGGATCAGG & ACCAACAGGACACTGCATGA \\
\hline PSPTOA0039 & GTCGGGGCAAAAATAAAGG & TCGTACTGCGGGTATCTGTT \\
\hline PSPTO3566 & TGATACTCACTCGCAAAGTAGGC & TATTGTGGGTCCTGGTTTGG \\
\hline PSPTO2298 & AAGAATTGATGCGCCGTTAC & GATTCCCGCAAATTTCTCAC \\
\hline PSPTO3123 & tgggcactgtactaccagca & aggcttgaagcatcttaccg \\
\hline hrpL (DC3000) & ttgtgatcctcgactcaacc & gggtcgatttgctgcttg \\
\hline avrPto & gagggtatacgaatgggaaatatatgtgtc & TTGCCAGTTACGGTACGGGCTAGGAGAAAG \\
\hline PSPTO4599 & cgggacaaagacgtttgc & ctgtccectgtccatacgat \\
\hline PSPTO0873 & ggaggttatcgtcggaatca & agtgcttgaaagggcaaaga \\
\hline PSPTO4589 & ctaaagcgccacggcatc & acactctgggcgecagtatc \\
\hline hrpL (NPS3121) & gactcttcgtctgecggtat & gggtcaatctgctgcttcaa \\
\hline hrpR (NPS3121) & taatgaacagcgegtttctg & agcaactcccaactccttca \\
\hline hrpR (DC3000) & gtcgaggtatcgagcgtctg & agcgataccctgggtgaact \\
\hline hrpS (DC3000) & caagctggatatctgcgtga & agcagtgggcaaacatcg \\
\hline rpoN (DC3000) & gaactcgacgaaatcgaagc & tcaatcgcttacgctcactg \\
\hline gacA (DC3000) & tgtcgatgaccatgacettg & gtgacgtacagcgagcaaag \\
\hline rhpS (DC3000) & TTGAATTCCAGGGAGCTGGGTTGA & TTTCTAGAGTCAAAGGCGCGGCAG \\
\hline PSPTO1453 & ATGTCCAATAGCAGCTCT & TCAGCTCAGCGTCACGTC \\
\hline PSPTO0507 & ATGGACATCATTCGTATC & TTACTTACGCGAAACGAT \\
\hline lon-1-G2 & AGTCTTAATGCGTGCTAATTCTATCCTTA & $\ldots$ \\
\hline lon-1-G1 & AGCAGATGCAGCGATAGCATCAATCAGTT & $\ldots$ \\
\hline TN-Tet-L1 & GTACCGGCATAACCAAGCCTATGCCTACAG & $\ldots$ \\
\hline TN-Tet-L2 & GAGGATGACGATGAGCGCATTGTTAGATTTC & $\ldots$ \\
\hline
\end{tabular}

${ }^{a}$ The PCR primers were designed based on DC3000 genomic sequence. 
soil. Disease symptoms were photographed 5 days after inoculation. Student's $t$ test was used for statistical analysis of the bacterial growth difference.

\section{ACKNOWLEDGMENTS}

This work was supported by the USDA NRI CSREES grant number 2005-35319-15299. Contribution number from Kansas State University Agricultural Research Experimental Station is 07-84. We thank B. Valent for critical reading and editing of the manuscript.

\section{LITERATURE CITED}

Bae, W., Xia, B., Inouye, M., and Severinov, K. 2000. Escherichia coli CspA-family RNA chaperones are transcription antiterminators. Proc. Natl. Acad. Sci. U.S.A. 97:7784-7789.

Bolstad, B. M., Irizarry, R. A., Astrand, M., and Speed, T. P. 2003. A comparison of normalization methods for high density oligonucleotide array data based on bias and variance. Bioinformatics 19:185-193.

Bretz, J., Losada, L., Lisboa, K., and Hutcheson S. W. 2002. Lon protease functions as a negative regulator of type III protein secretion in Pseudomonas syringae. Mol. Microbiol. 45:397-409.

Buell, C.R., Joardar, V., Lindeberg, M., Selengut, J., Paulsen, I. T., Gwinn, M. L., Dodson, R. J., Deboy, R. T., Durkin, A. S., Kolonay, J. F., Madupu, R., Daugherty, S., Brinkac, L., Beanan, M. J., Haft, D. H., Nelson, W. C., Davidsen, T., Zafar, N., Zhou, L., Liu, J., Yuan, Q., Khouri, H., Fedorova, N., Tran, B., Russell, D., Berry, K., Utterback, T., Van Aken, S. E., Feldblyum, T. V., D'Ascenzo, M., Deng, W. L., Ramos, A. R., Alfano, J. R., Cartinhour, S., Chatterjee, A. K., Delaney, T. P., Lazarowitz, S. G., Martin, G. B., Schneider, D. J., Tang, X., Bender, C. L., White, O., Fraser, C. M., and Collmer, A. 2003. The complete genome sequence of the Arabidopsis and tomato pathogen Pseudomonas syringae pv. tomato DC3000. Proc. Natl. Acad. Sci. U.S.A. 100:1018110186.

Carballido-Lopez, R., Formstone, A., Li, Y., Ehrlich, S. D., Noirot, P., and Errington, J. 2006. Actin homolog MreBH governs cell morphogenesis by localization of the cell wall hydrolase LytE. Dev. Cell 11:399-409.

Cascales, E., and Lloubes, R. 2004. Deletion analyses of the peptidoglycan-associated lipoprotein $\mathrm{Pal}$ reveals three independent binding sequences including a TolA box. Mol. Microbiol. 51:873-885.

Chang, J. H., Urbach, J. M., Law, T. F., Arnold, L. W., Hu, A., Gombar, S., Grant, S. R., Ausubel, F. M., and Dangl, J. L. 2005. A high-throughput, near-saturating screen for type III effector genes from Pseudomonas syringae. Proc. Natl. Acad. Sc. U.S.A. 102:2549-2554.

Chatterjee, A., Cui, Y., Yang, H., Collmer, A., Alfano, J. R., and Chatterjee, A. K. 2003. GacA, the response regulator of a two-component system, acts as a master regulator in Pseudomonas syringae pv. tomato DC3000 by controlling regulatory RNA, transcriptional activators, and alternate sigma factors. Mol. Plant-Microbe Interact. 6:1106-1117.

Croteau, D. L., DellaVecchia, M. J., Wang, H., Bienstock, R. J., Melton, M. A., and Van Houten, B. 2006. The C-terminal zinc finger of UvrA does not bind DNA directly but regulates damage specific DNA binding. J. Biol. Chem. 281:26370-26381.

Ferreira, A. O., Myers, C. R., Gordon, J. S., Martin, G. B., Vencato, M., Collmer, A., Wehling, M. D., Alfano, J. R., Moreno-Hagelsieb, G., Lamboy, W. F., DeClerck, G., Schneider, D. J., and Cartinhour, S. W. 2006. Whole-genome expression profiling defines the HrpL regulon of Pseudomonas syringae pv. tomato DC3000, allows de novo reconstruction of the Hrp cis element, and identifies novel coregulated genes. Mol. Plant-Microbe Interact. 19:1167-1179.

Fouts, D. E., Abramovitch, R. B., Alfano, J. R., Baldo, A. M., Buell, C. R., Cartinhour, S., Chatterjee, A. K., D'Ascenzo, M., Gwinn, M. L., Lazarowitz, S. G., Lin, N. C., Martin, G. B., Rehm, A. H., Schneide, D. J., van Dijk, K., Tang, X., and Collmer, A. 2002. Genomewide identification of Pseudomonas syringae pv. tomato DC3000 promoters controlled by the HrpL alternative sigma factor. Proc. Natl. Acad. Sci. U.S.A. 99:2275-2280.

Grimm, C., Aufsatz, W., and Panopoulos, N. J. 1995. The hrpRS locus of Pseudomonas syringae pv. phaseolicola constitutes a complex regulatory unit. Mol. Microbiol. 15:155-165

Heeb, S., and Haas, D. 2001. Regulatory roles of the GacS/GacA twocomponent system in plant-associated and other gram-negative bacteria. Mol. Plant-Microbe Interact. 14:1351-1363.

Hendrickson, E. L., Guevera, P., and Ausubel. F. M. 2000. The alternative sigma factor RpoN is required for hrp activity in Pseudomonas syringae pv. maculicola and acts at the level of $h r p L$ transcription. J. Bacteriol. 182:3508-3516.

Howard-Flanders, P., Simson, E., and Theriot, L. 1964. A locus that con- trols filament formation and sensitivity to radiation in Escherichia coli K-12. Genetics 49:237-246.

Hutcheson, S. W., Bretz, J., Sussan, T., Jin, S., and Pak, K. 2001. Enhancer-binding proteins HrpR and HrpS interact to regulate hrp-encoded type III protein secretion in Pseudomonas syringae strains. J. Bacteriol. 183:5589-5598.

Huynh, T. V., Dahlbeck, D., and Staskawicz, B. J. 1989. Bacterial blight of soybean: regulation of a pathogen gene determining host cultivar specificity. Science 245:1374-1377.

Irizarry, R. A., Hobbs, B., Collin, F., Beazer-Barclay, Y. D., Antonellis, K. J., Scherf, U., and Speed, T. P. 2003. Exploration, normalization, and summaries of high density oligonucleotide array probe level data. Biostatistics 4:249-264.

Jackson, M. W., Silva-Herzog, E., and Plano, G. V. 2004. The ATP-dependent ClpXP and Lon proteases regulate expression of the Yersinia pestis type III secretion system via regulated proteolysis of YmoA, a small histone-like protein. Mol. Microbiol. 54:1364-1378.

Johnson. D. C., Dean, D. R., Smith, A. D., and Johnson, M. K. 2005. Structure, function, and formation of biological iron-sulfur clusters. Annu. Rev. Biochem. 74:247-281.

King, E. O., Ward, M. K., and Raney, D. E. 1954. Two simple media for the demonstration of pyocyanin and fluorescein. J. Lab. Med. 22:301-307.

Kuroda, A. 2006. A polyphosphate-lon protease complex in the adaptation of Escherichia coli to amino acid starvation. Biosci. Biotechnol. Biochem. 70:325-331

Kuroda, A., Nomura, K., Ohtomo, R., Kato, J., Ikeda, T., and Takiguchi, N. 2001. Role of inorganic polyphosphate in promoting ribosomal protein degradation by the Lon protease in E. coli. Science 293:705-708.

Lan, L., Deng, X., Zhou, J., and Tang, X. 2006. Genome-wide gene expression analysis of Pseudomonas syringae pv. tomato DC3000 reveals overlapping and distinct pathways regulated by $h r p L$ and $h r p R S$. Mol. Plant-Microbe Interact. 19:976-987.

Lindeberg, M. S., Cartinhour, S., Myers, C. R., Schechter, L. M., Schneider, D. J., and Collmer, A. 2006. Closing the circle on the discovery of genes encoding Hrp regulon members and type III secretion system effectors in the genomes of three model Pseudomonas syringae strains. Mol. Plant-Microbe Interact. 19:1151-1158.

Losada, L. C., and Hutcheson, S. W. 2005. Type III secretion chaperones of Pseudomonas syringae protect effectors from Lon-associated degradation. Mol. Microbiol. 55:941-953.

Markovitz, A. 1964. Regulatory mechanisms for synthesis of capsular polysaccharide in mucoid mutants of Escherichia coli K-12. Proc. Natl. Acad. Sci. U.S.A. 51:239-246.

Meddows, T. R. Savory, A. P., Grove, J. I., Moore, T., and Lloyd, R. G. 2005. RecN protein and transcription factor DksA combine to promote faithful recombinational repair of DNA double-strand breaks. Mol. Microbiol. 57:97-110.

Petnicki-Ocwieja, T., Schneider, D. J., Tam, V. C., Chancey, S. T., Shan, L., Jamir, Y., Schechter, L. M., Janes, M. D., Buell, C. R., Tang, X., Collmer, A., and Alfano, J. R. 2002. Genomewide identification of proteins secreted by the Hrp type III protein secretion system of Pseudomonas syringae pv. tomato DC3000. Proc. Natl. Acad. Sci. U.S.A. 99:7652-7657.

Rahme, L. G., Mindrinos, M. N., and Panopoulos N. J. 1992. Plant and environmental sensory signals control the expression of hrp genes in Pseudomonas syringae pv. phaseolicola. J. Bacteriol. 74:3499-3507.

Robertson, G. T., Kovach, M. E., Allen, C. A., Ficht, T. A., and Roop, R. M. II. 2000. The Brucella abortus Lon functions as a generalized stress response protease and is required for wild-type virulence in BALB/c mice. Mol. Microbiol. 35:577-588.

Roine, E., We, W., Yuan, J., Nurmiaho-Lassila, E. L., Kalkkinen, N., Romantschuk, M., and H, S. Y. 1997. Hrp pilus: an hrp-dependent bacterial surface appendage produced by Pseudomonas syringae pv. tomato DC3000. Proc. Natl. Acad. Sci. U.S.A. 94:3459-3464.

Romeo, T. 1998. Global regulation by the small RNA-binding protein CsrA and the non-coding RNA molecule CsrB. Mol. Microbiol. 29:1321-1330.

Schechter, L. M., Vencato, M., Jordan, K. L., Schneider, S. E., Schneider, D. J., and Collmer, A. 2006. Multiple approaches to a complete inventory of Pseudomonas syringae pv. tomato DC3000 type III secretion system effector proteins. Mol. Plant-Microbe Interact. 19:1180-1192.

Schoemaker, J., Gayda, R., and Markovitz, A. 1984. Regulation of cell division in Escherichia coli: SOS induction and cellular location of the SulA protein, a key to Lon-associated filamentation and death. J. Bacteriol. 158:551-561.

Shan, L., Thara, V. K., Martin, G. B., Zhou, J. M., and Tang, X. 2000. The Pseudomonas AvrPto protein is differentially recognized by tomato and tobacco and is localized to the plant plasma membrane. Plant Cell 12:2323-2338.

Stewart, B., Enos-Berlage, J., and McCarter, L. 1997. The lonS gene regu- 
lates swarmer cell differentiation of Vibrio parahaemolyticus. J. Bacteriol. 179:107-114.

Su, S., Stephens, B. B., Alexandre, G., and Farrand, S. K. 2006. Lon protease of the alpha-proteobacterium Agrobacterium tumefaciens is required for normal growth, cellular morphology and full virulence. Microbiology 152:1197-1207.

Swinger, K. K., and Rice, P. A. 2004. IHF and HU: flexible architects of bent DNA. Curr. Opin. Struct. Biol. 14:28-35.

Takaya, A., Kubota, Y., Isogai, E., and Yamamoto, T. 2005. Degradation of the HilC and HilD regulator proteins by ATP-dependent Lon protease leads to downregulation of Salmonella pathogenicity island 1 gene expression. Mol. Microbiol. 55:839-852.

Tang, X., Xiao, Y., and Zhou, J.-M. 2006. Regulation of the type III secretion system in phytopathogenic bacteria. Mol. Plant-Microbe Interact. 19:1159-1166.

Thwaites, R., Spanu, P. D., Panopoulos, N. J., Stevens, C., and Mansfield, J. W. 2004. Transcriptional regulation of components of the type III secretion system and effectors in Pseudomonas syringae pv. phaseolicola. Mol. Plant-Microbe Interact. 17:1250-1258.

Torres-Cabassa, A., and Gottesman, S. 1987. Capsule synthesis in Escherichia coli K-12 is regulated by proteolysis. J. Bacteriol. 169:981-989.

Tsilibaris, V., Maenhaut-Michel, G., and Van Melderen, L. 2006. Biological roles of the Lon ATP-dependent protease. Res. Microbiol. 157:701-713

Whistler, C. A., Stockwell, V. O., and Loper, J. E. 2000. Lon protease in- fluences antibiotic production and UV tolerance of Pseudomonas fluorescens Pf-5. Appl. Environ. Microbiol. 66:2718-2725.

Xiao, Y., and Hutcheson, S. W. 1994. A single promoter sequence recognized by a newly identified alternate sigma factor directs expression of pathogenicity and host range determinants in Pseudomonas syringae. J. Bacteriol. 176:3089-3091.

Xiao, Y., Heu, S., Yi, J., Lu, Y., and Hutcheson S. W. 1994. Identification of a putative alternate sigma factor and characterization of a multicomponent regulatory cascade controlling the expression of Pseudomonas syringae pv. syringae Pss61 hrp and hrmA genes. J. Bacteriol. 176:1025-1036.

Xiao, Y., Lan, L., Yin, C., Deng, X., Baker, D. W., Zhou, J.-M., and Tang, X. 2007. Two-component sensor RhpS promotes induction of Pseudomonas syringae type III secretion system by repressing negative regulator RhpR. Mol. Plant-Microbe Interact. 20: 223-234.

Zwiesler-Vollick, J., Plovanich-Jones, A. E., Nomura, K., Bandyopadhyay, S., Joardar, V., Kunkel, B. N., and He S. Y. 2002. Identification of novel hrp-regulated genes through functional genomic analysis of the Pseudomonas syringae pv. tomato DC3000 genome. Mol. Microbiol. 45:12071218.

\section{AUTHOR-RECOMMENDED INTERNET RESOURCE}

NimbleGen Systems high-definition genomics webpage: www.nimblegen.com 